\title{
Kamu Politikası Analizi Açısından Türkiye'de Kripto Para Politikaları
}

Osman Gökhan HATIPPOĞLU ${ }^{1}$

Makale Gönderim Tarihi: 28 Ağustos 2021

Makale Kabul Tarihi: 20 Eylül 2021

\section{$\ddot{O} z$}

Bu çalışmada Türkiye'de kripto paralarla ilgili kamu politikalarının analiz edilmesi amaçlanmaktadır. İki aşamalı analizde ilk olarak kripto paraların beraberinde getirdiği politika sorunları kamu politikası disiplinindeki sorun konsepti çerçevesinde açıklanmaktadır. İkinci aşamada ise açıklaması yapılmış politika sorunlarına ilişkin kamusal alandaki politika aktörlerinin tutumu, politika döngüsünün gündem aşaması üzerinden ve aktörlerin aldıklar1 ve/veya almadıkları kararlar üzerinden tahlil edilmiştir. Türkiye'de kripto paraların yarattığı sorunlara kesin bir çözüm üretilmeyerek, sorunun gündem aşamasında kaldığ 1 ve politika döngüsünün bundan sonraki aşamalarının devreye giremediği tespit edilmiştir. Çalışma sonucunda kripto paralarla ilgili kamusal alanındaki aktörlerin karar verici ve politika üretici TBMM'ni veya Cumhurbaşkanlığı'nı yönlendirmesi gerektiği sonucuna varılmıştır.

Anahtar Kelimeler: Kripto paralar, kamu politikası analizi, politika gündemi, politika sorunu.

JEL Sinıflandırması: D78, G28, H83, H87.

1 Dr. Öğr. Üyesi, Yozgat Bozok Üniversitesi, İ.İ.B.F. Siyaset Bilimi ve Kamu Yönetimi Bölümü, gokhan.hatipoglu@bozok.edu.tr, ORCID: 0000-0003-3045-4751 


\title{
Crypto Monetary Policies in Turkey in terms of Public Policy Analysis
}

\begin{abstract}
In this study, it is aimed to analyze the public policies regarding cryptocurrencies in Turkey. In this two-stage analysis, problems brought by cryptocurrencies are explained according to public policy discipline. Then the attitude of state policy actors is analyzed over the agenda phase of the policy cycle and the decisions taken and/or not taken by them. It has been determined that no solution to the policy problems has yet not been produced in Turkey, rather the problem remains in the agenda and the next stages of the policy cycle cannot be activated. As a result of the study, it was concluded that the actors in the public sphere should direct the decision-maker and policy-maker Parliament or the Presidency about cryptocurrency policies.
\end{abstract}

Keywords: Cryptocurrencies, public policy analysis, policy agenda, policy issue.

JEL Code: D78, G28, H83, H87.

\section{Giriş}

Kripto paralar internetle birlikte gelişen finansal teknolojilerin yarattığ 1 kavram ve ürünlerden biridir. Bu teknolojiler, genellikle yerleşik bankalar ve aracılar gibi hizmet sunucuları tarafindan sunulmakta olan finansal hizmetleri ayrıştırarak çoğunlukla internet kullanımıyla otomatikleştirilmiş biçimde sunmaktadır (Görmez, 2017, s. 7-8). Finansal teknoloji ile banka ve diğer resmi aracıları devre dışı bırakan, denkler-arası borçlanma, kitle fonlaması, akıllı sözleşmeler, robo-tavsiye, sanal para ve dağıtılmış defter uygulamaları gibi yeni finansal araç ve teknikler son on yılda birçok ülkenin de kamu politikası gündemine taşınmaktadır. Bu yeni ürün ve teknikler internetin yaygın ve etkin kullanımı, değişen finansal kültür ve artan finansal okur yazarlık nedeni ile çok hızlı olarak yayılmakta ve kısa zamanda büyük kullanıcı kitleleri tarafindan tercih edilebilmektedir. Kamu otoriteleri ise politika üretme konusunda yeni finansal hizmetler ve ürünlerin bu hızına yetişmekte zorlanmaktadır. Aralarında Türkiye'nin de bulunduğu birçok ülke konvansiyonel olmayan bu karmaşık ürünleri düzenlemek için yeterli hukuki araçların ve düzenlemelerin geliştirilmesinde sorun yaşamaktadır.

Çalışmanın temel amacı Türkiye'de kripto paralarla ilgili politika sorunlarının yoğunlaştığı alanları betimlemek ve kamusal alandaki TCMB, 
SPK, BDDK, Hazine ve Maliye Bakanlığı gibi politika tasarlaması ve uygulaması beklenen aktörlerin kripto paraların beraberinde getirdiği sorunlarla ilgili tutumlarını analiz etmektir. Kripto paralar Türkiye'nin hukuk ve finans sisteminde belirsizlikler ve kamu aktörlerince düzenlenmesi gereken boşluklar yaratmaktadır. Diğer yandan bu belirsizlikler ve boşluklar nedeni ile kripto para kullanıcılarının maruz kaldığı dolandırıcılık, spekülasyon ve hırsılık gibi çok yönlü riskler söz konusudur. Çalışmanın ilk aşaması bu iki alandaki politika sorunlarının sınıflandırılmasıyla tamamlanmıştır. Analizin ikinci aşamasında ise açıklaması yapılmış politika sorunlarına ilişkin kamu sektöründe yer alan politika aktörlerinin tutumu, politika döngüsünün gündem fazı üzerinden ve politika aktörlerinin aldıkları ve/veya almadıkları kararlar üzerinden tahlil edilmiştir. Bu tercihte kripto paraların yarattığı sorunlara kesin bir çözüm üretilmeyerek, sorunun gündem aşamasında kalması ve politika döngüsünün bundan sonraki aşamalarının devreye sokulmamış olması etkili olmuştur. Bu çalışmanın güdüleyici nedeni Türkiye'de kripto para politikalarını kamu politikası disiplini açısından inceleyen analitik bir araştırmanın eksikliği olmuştur. Güncel bir politika sorununu aktör, problem ve gündem gibi politika analizi disiplini unsur ve araçlarını kullanarak ele alan bu çalışmanın hem kripto paralarla ilgili yönetim alanında yapılacak daha ileri araştırmalar için yararlı olacağı, hem de yöntemleri itibarıyla politika analizi pratiği açısından katkı sağlayacağı düşünülmektedir.

Türkiye'deki yaygın kullanımına ve beraberinde getirdiği sorunlara rağmen 2013 y1lından bu yana politika gündeminde olan kripto paralarla ilgili kanun düzeyinde henüz tek bir yasal düzenleme bile yapılmamıştır. Bir başka deyişle kripto para politikaları uzunca bir süredir politika sürecinin gündem aşamasında kalmış, politika sürecinin diğer basamaklarına geçilememiş̧ir. Bu nedenle bu çalışmada politika analizi sadece politika sorunu, gündem ve karar verici aktörler üzerinden yapılabilmiştir. Yapılan analizde ilk olarak kripto paraların beraberinde getirdiği problemler kamu politikası disiplinindeki politika sorunu kavramı dahilinde ele alınmıştır. Daha sonra Türkiye'de kripto paranın politika gündemine taşınma süreci, kripto paralarla ilgili politika aktörleri ve bu aktörlerin kripto para ile ilgili gündemleri tahlil edilmiştir. Son olarak dünyadaki kripto para politikaları karşılaştırmalı olarak gözden geçirilerek, Türkiye'nin kripto politikaları hakkında genel bir değerlendirme yapılmıştır.

\section{Bir Kamu Politikası Sorunu Olarak Kripto Paralar}

Kripto paralar, bankaların ve diğer finansal aracıların kullandığı merkezi kayıt esaslı dijital ödeme ve kayıt sistemlerinden farklı ve bunlara bir al- 
ternatif olarak internet üzerinde geliştirilen, birbirini tanımayan kullanıcıların konsensüsüne dayalı dağıtık defter teknolojisinin bir ürünüdür. Kripto paralar bilgisayar ağları üzerinden güvenli, aracısız ve ucuz para transferi ihtiyacına bir yanıt olarak yeni ve ademi merkeziyetçi bir elektronik ödeme sistemi olarak geliştirilmiştir. Martucci'ye (2019) göre kripto paralar ya da sanal paralar özel şahıs veya gruplar tarafından yaratılmış olan dijital mübadele (exchange) araçlarıdır. Dijital itibari paraların işlemlerinde, güvenilen bir aracıya ihtiyaç duyulurken, kripto paralarda aracıya ve güvene ihtiyaç yoktur. Politik olarak bağımsız ve neredeyse aşılamaz bir veri güvenliği olan kripto paraların kullanıcıları iki temel avantajdan yararlanır. Birincisi hükümetlerin kontrolü altındaki paraları kolaylıkla dondurma ya da el koyma olasılığı varken, bu durum kendi vatandaşı bile olsa kripto para sahipleri için söz konusu değildir. İkincisi ise kripto para sahipliğinin anonim olması yani bu şekilde tutulan bir mal varlığı bilgisinin gizli kalmasıdır (Martucci, 2019).

Kısaca, kripto paralar mükerrer işlemlere karşı korunakl1, karşıl1klı güven gereksinimi olmadan mübadele olanağı sağlayan, dijital saldırılara karşı güvenli bir sanal değişim aracı olarak kaydi ve dijital paraya karşı ucuz bir seçenek sağlamaktadır. Kripto paraların güven ve ucuzluk dışındaki üçüncü avantajı ise anonim olmasıdır. Ancak kullanıcılar için sağlanan bu avantaj kamunun düzenleyici ve kontrol edici işlevlerini etkisizleştirdiğinden, finansal kurumlar için bir dezavantaj teşkil etmektedir. Kripto paraların zaman içinde değer kazanması ise yeni bir yatırım aracı olarak ön plana çıkmasına neden olmuştur. Kripto paralar özellikle kullanıcıları açısından bazı avantajlar sağlamakla beraber, taşıdığı riskler nedeniyle hem kullanıcılar açısından hem de kuralsız ve düzenlenmemiş bir finansal araç olarak görüldüğü kamu yönetimi aktörleri açısından bir kamu politikası sorunu olarak ele alınmayı gerektirmektedir.

Kamu politikası disiplinin temel amac1 politikanın yapılmasını gerektiren bu türden sorunları analiz etmek ve çözmektir. Disiplin açısından, politika sorunu, sorunun sahibi politika aktörünün arzu ettiği amaç ile mevcut veya gelecekte beklenen gerçeklik arasında algılanan farklılıktır. Diğer bir deyişle politika sorunu normatif bir ilke veya hedef ile mevcut (algılanan) durum arasındaki açıklıktır (Bardach \& Patashnik, 2016, s. 71). Kamu politikası sürecinin ve bu süreci aşamalı bir döngü olarak açıklayan kamu politikası işleyiş̧i modelinin ilk aşaması politika sorununun ortaya çıkması ve tanımlanmasıdır. Bu döngüsel modelde süreç politika sorununun karar vericilerin gündeme alınmasıyla başlar. Politika süreci çözüm seçeneklerinin incelenmesi, ardından karar verme, uygulama ve değerlendirme aşamaları ile devam eder (Parsons, 1995, s. 77). Söz konusu geleneksel modelin açılayıcılığını savu- 
nanlara göre kamu politikası analizinde yaygın olarak kullanılan bu aşamacı (stagist) yaklaşım her türlü eleştiriye rağmen hem politika sürecinde hem de analizinde temel modeldir (Parsons, 1995, s. 77-78; Jahn \& Wegrich, 2007, s. 43). Geleneksel aşamacı modellerde aşama sayıları değişse de, temel izlek aşağ1 yukarı aynıdır ve kamu politikasının nesnesi olan sorunun tanımlanması ve gündeme gelmesi doğal olarak her zaman ilk sırada yer alır. Aslında herhangi bir kamu politikasının üretilmesi sorunun tanımlanmasını da içeren bir süreçtir. Bunun için de sorun konusu olan meselenin politikayı üretenler tarafindan nasıl algılandığ 1 ve sorun olarak görülüp görülmemesi önemlidir (Parson, 1995, s. 87). Politika sorununu diğer bilimlerdeki sorunlardan ayıran şey ise karmaşıklığıdır; çoğunlukla sorunun nerede başladığı veya nerede bittiği belirli değildir (Parsons 1995, s. 88-89).

Kripto paraların yarattı̆ğ sorunların da sınırları belirli değildir. Ancak hızla gelişip kontrol dışı bir yatırım aracı haline gelmesi, otoritelerin kontrolünden çıkması ve mülkiyetinin anonimliği kamu yöneticileri açısından problem olarak algılanmasına neden olmaktadır. Kullanıcılar ise aslında avantajlarından yararlandıkları bu yeni enstrümanla ilgili risklere maruz kaldıkça kripto para kullanımın sorunlu yönlerini algılamaya başlamışlardır. Yarattığı problemli durumlar değerlendirilerek kripto paraları hem kamu sektöründeki aktörler hem de kullanıcılar için politika sorunu haline getiren unsurlar Tablo 1 'de sinıflandırılmıştır. 
Tablo 1. Türkiye'de Kripto Paralarla İlgili Politika Sorunları (*)

\begin{tabular}{|c|c|c|c|}
\hline Sorun bașlığı & Sorunun Kapsamı & Politika Aktörleri & Politika Gündemi/Tasarılan \\
\hline $\begin{array}{l}\text { Regülasyon İhtiyacı/Finansal sistemin } \\
\text { dışında kalmak }\end{array}$ & $\begin{array}{l}\text { Merkez Bankası kontrolü dışında } \\
\text { ödeme ve para sistemlerinin para } \\
\text { politikalarında sorun yaratmaktadır }\end{array}$ & TCMB, Cumhurbaşkanlığı & $\begin{array}{l}\text { Kripto paranın para olarak tanımlanarak işlemlerinin } \\
\text { Merkez Bankası gözetim ve kontrolüne verilmesi, } \\
\text { Yasaklanması veya Merkez Bankası tarafından } \\
\text { kripto para ihdas edilmesi }\end{array}$ \\
\hline $\begin{array}{l}\text { Hukuk sisteminin dışında kalmak ve } \\
\text { hukuki boşluk yaratmak }\end{array}$ & $\begin{array}{l}\text { Kripto paralarla ilgili hukuki boşluk } \\
\text { borçlar kanunu, medeni kanun ve } \\
\text { Vergi Usul Kanununda uygulama } \\
\text { sorunları yaratmaktadır }\end{array}$ & TBMM, Cumhurbaşkanlığı & $\begin{array}{l}\text { Kripto paraların mal veya emtia olarak ve ödeme } \\
\text { aracı olarak hukuk sistemine alınmasını sağlayacak } \\
\text { yasalar çıkarmak }\end{array}$ \\
\hline Dolandırıcılık/ Siber hırsızlık & $\begin{array}{l}\text { Dolandırıcılık ve sahtecilik } \\
\text { durumunda hukuki takibin } \\
\text { yapılamamaktadır }\end{array}$ & $\begin{array}{l}\text { TCMB, BDDK, TBMM, } \\
\text { MASAK, Mali Suçla İlgili } \\
\text { Kolluk Birimleri }\end{array}$ & $\begin{array}{l}\text { TCMB tarafından kripto para yaratılması, Elektronik } \\
\text { para kapsamına alınıp BDDK tarafından } \\
\text { denetlenmesi, Ceza Hukuku ve İlgili kanunlarda } \\
\text { değişiklik, Mali ve Siber Suçlarla Mücadele } \\
\text { nolitikalarında revizvon }\end{array}$ \\
\hline Para Aklamada Kullanılmak & $\begin{array}{l}\text { Kripto paranın izlenmesinin zor } \\
\text { olması ve anonimliği kayıt dışı } \\
\text { paraların aklanmasını sağlamaktadır }\end{array}$ & $\begin{array}{l}\text { Hazine ve Maliye Bakanlığı, } \\
\text { BDDK, SPK }\end{array}$ & $\begin{array}{l}\text { Kripto para işlemlerinini yasaklanması veya kayıt } \\
\text { altına alınması }(* *)\end{array}$ \\
\hline Finansal/spekülatif riskler & $\begin{array}{l}\text { Kripto para değerlerindeki } \\
\text { oynaklıklar ve dalgalanmalar } \\
\text { finansal kayıplara neden olmaktadır. }\end{array}$ & Hazine ve Maliye Bakanlığı & Yasaklama, kamuoyunu bilgilendirme \\
\hline Maliye/Vergi Sorunları & $\begin{array}{l}\text { Kripto paranın mevzuatta } \\
\text { tanımlanmamış olması ve/veya } \\
\text { kazançlarının vergi kapsamında } \\
\text { düzenlenmemesi vergi kaybına } \\
\text { neden olmaktadır }\end{array}$ & $\begin{array}{l}\text { Cumhurbaşkanlığı, Maliye } \\
\text { Bakanlığı, BDDK, SPK, } \\
\text { Bankalar }\end{array}$ & $\begin{array}{l}\text { Kripto paranın mal veya emtia olarak tanımlanması, } \\
\text { kripto para borsalarının kayıt ve denetim altına } \\
\text { alınması, zorunlu bildirim yükümlülüğü }\end{array}$ \\
\hline
\end{tabular}

Tablo 1'de görüleceği üzere kripto paraların kullanıcılar ve/veya kamu otoriteleri açısından yarattığı politika sorunları, bu sorunların alanlarına göre altı sınıfta gruplandırılmıştır. Sorunların başlıkları ve kapsamları çalışmanın bu bölümünde detaylı olarak analiz edilmiştir. Tablodaki ilgili politika aktörleri sütununda sıralanan kurumlar ve sorunların olası çözümlerine dair politika gündemindeki gelişmeler ve tasarılar ise çalışmanın bir sonraki bölümünde ele alınmıştır.

\subsection{Regülasyon İhtiyacı /Finansal sistemin dıșında kalmak}

Kripto paraların önceden de açıklandığı üzere dağıtık defter teknolojisi ile yapılan kayıtlama düzeni nedeniyle merkezi bir yönetimi yoktur. Arzı ve değeri kullanıcıların eylemleri ve kendi yönetim kodlarına sahip karmaşık protokollerle belirlenmektedir. Kripto paralar bu yönü ile merkez bankaları veya diğer düzenleyici otoritelerin bilinçli kararları ile yönetilen para birimlerinden tamamen farklıdır (Martucci, 2019). Bu durum kripto paralarla ilgili düzenleme yapılmasını da zorlaştırmaktadır. Politika yapıcılar paralarla ilgili finansal yasa ve düzenlemelerinin çoğunu kripto paraların icadı ve takip eden yayılma döneminden önce gerçekleştirmiştir (CRS, 2018, s. 15). Bu nedenle özel kişi ve gruplarca anonim olarak yaratılan kripto paralar ülkelerin merkezi para ve ödeme sisteminin sınırları dışında kalmaktadır. Kripto paraların 
pek çoğu ulusal hükümetler tarafından düzenlemeye tabi tutulmadıkları için devletin parasal politika sınırlarının dışında kalan finansal bir mübadele aracı, alternatif döviz birimleri olarak ortaya çıkmaktadır (Martucci, 2019) Merkez Bankası'nın tek para otorite olmasının yani devletin para tekelinin ve para politikalarının etkinliğinin sürdürülmesinin önemi de kripto paralar konusunda hükümetleri koruyucu ve denetleyici politikalara yöneltmektedir (Aydoğan, 2019, s. 89).

Türkiye 2020 y1lında nüfusun \%16'sına ulaşan kripto para kullanımı/uyumu (adoption) oranı ile dünyada 4. sırada yer almaktadır (Buchholz, 2020). Bir başka şaşırtıcı istatistik ise kripto para sahiplerinin sayısı alanında olup, Türkiye 2018 yılında dünyada en fazla kripto para sahibinin bulunduğu ülkedir²(Milijic, 2019). Resmi istatistikleri tutulamadığı için ancak aracı borsalardan derlenen bilgiler üzerinden tahmini olarak yapılan analizlere göre ülkede 2021 yılında yapılan günlük ortalama 300.000 adet kripto para işlemi, adet olarak Borsa İstanbul'daki günlük işlem hacminin 4'tel'ine ulaşmıştır (Yüksel, 2021; Statista, 2021). Bütün bu istatistikler Türkiye'de kripto para kullanımının hızla yaygınlaştığını göstermesi açısından anlamlıdır ve ülkeyi kripto paralarla ilgili risklere karşı hassas kılmaktadır.

Yeterli hukuki ve sistemsel düzenlemelerin eksik olduğu Türkiye'de bahsedilen işlem hacimlerine ulaşan kripto paraların devletçe düzenlenmiş finansal sistemin dışında kalması, ödeme sistemleri, itibari para otoriteleri ve örgütlü sermaye piyasaları açısından kuralsız bir alan, bir boşluk yaratmaktadır. Ülkede kripto paralarla ilgili yasal bir tanımın yapılmış olmaması, üstelik bunların bir yatırım aracı olarak kullanılması, mülkiyet konusu olup olmadığının hukuk açısından gri alanda kalması, sahipliğinin anonim olması ve sisteminin belirli bir merkezi olmayacak şekilde dağınık olarak yapılanması gibi nedenler belirgin bir kamu politikası üretilmesini zorlaştırmaktadır. Politika eksikliğinin yarattı̆̆ belirsizlik kripto para kullanıcılarının Diyanet İşleri Başkanlığı'na dahi danışmasına neden olmaktadır³. Sonuçta Türkiye'de kripto para ile ilgili belirsizliklerin giderilmesi yönünde ivedi bir gereksinim olduğu açıktır. Gerekli düzenlemelerin, finansal tabiri ile regülasyonların eksikliği kripto paraları bir politika problemi olarak son birkaç yıldır dönemsel

2 Milijic'e göre (2019) bu yüksek oranın, Türk halkının kripto para kullanımı yönündeki belirgin istekliliğinin ana nedeni bankalara güvenin az olması ve uluslararası tansiyona bağlı olarak Türk Lirasının sık sık değer kaybetmesidir.

3

Başkanlığa bağlı Yüksek Kurul 2017 y1lında kendisine iletilen sorular üzerine "sanal paraların teminat altında olmaması" sebebi ile; 2018 y1lında ise "belirli kesimlerin haksız ve sebepsiz zenginleşmesine yol açtığı" gerekçeleriyle dijital kripto paraların kullanımının caiz olmadığına hükmetmiştir (İndigo Dergisi, 2017; TRT Haber, 2018a). 
olarak BDDK, SPK, MASAK, TCMB gibi düzenleyici aktörlerin gündemine getirmektedir.

\subsection{Hukuk sisteminin dışında kalmak ve hukuki boşluk yaratmak}

Kripto paralarla ilgili düzenlemelerin bir önceki başlıkta betimlenmiş olan eksikliği nedeniyle finansal ve mali sistemde yaşanılan politika sorununun bir benzeri hukuk sisteminde de görülmektedir. Kripto paralar halen Türk hukuk sisteminde bir emtia veya bir para/ödeme aracı olarak tanımlı değildir. $\mathrm{Bu}$ durum fiili olarak ticaret ve finans dünyasında kullanılmakta olan ve maddi bir değere tekabül eden bu varlıklarla ilgili olarak hukuk dünyasında boşluklar doğmasına neden olmuştur. Turhan'a göre kripto paraların henüz bir mevzuatının olmaması bunları mevzuattan ari kılmamakta, aksine tüm mevzuata muhatap kılmaktadır. Uyar'a (2018) göre mevzuatın olmadığı sanal paralarla ilgili hukuki boşluk doldurulmak zorundadır. Kripto paraların ticari bir mal olmasının ${ }^{4}$ yanı sıra bir ödeme aracı olması hali ise başka bir hukuki sorunu beraberinde getirmektedir. Kripto paralar ürün satışlarında, personel ödemelerinde ve taşınmaz satışlarında bile kullanılabilmektedir. Kripto paraların bu şekilde kullanılmasının, ancak ticari emtia olarak sayılması durumunda takas sözleşmeleri ile mümkün olabileceğini vurgulayan Uyar'a göre (2018), kripto paralar hakkında, emtia ya da menkul kıymet, genel bir ifadeyle" mal varlı̆̆ı" oldukları yönünde bir yasal düzenleme henüz yapılmamıştır. Tüm bu hukuki boşluk uyarılarının haklılığı çalışmanın bir sonraki bölümünde açıklanacağ 1 gibi Türkiye'de 2021 yılında yaşanan suç vasfındaki gelişmelerle teyit edilmiştir. Kripto paraların çalınması ve/veya dolandırılması durumunda varlık olmama durumunun ceza hukukunda yarattığı boşluklar, hukukun diğer dallarında da yaşanmaktadır. Örneğin mülkiyet tanımına uymayan yönleri nedeni ile özellikle vasiyetsiz ölümlerde kripto paraların miras hukukuna konu olmas1 durumunda da benzer bir hukuki belirsizlik söz konusudur (Uyar, 2018; Kaplanhan, 2018, s. 113). Özetle, kripto paralar Türk hukuk sisteminde hem var hem yok konumdadır. Kripto paraların hukuk dünyasında açıkça tarif edilmemesi, daha doğrusu hali hazırda var olmaması, ancak hukuk felsefesi araçlarına başvurularak, yorum ve kıyasla çözülebilecek karmaşık sorunların gündeme gelmesine neden olmaktadır. Bu durum kripto paraların hukukun birçok alanında yarattığı boşlukları başlı başına bir politika sorunu haline getirmektedir.

4 Bitcoin, taşınır, ticareti yapılabilir bir emtia olarak emtia borsalarında işlemlere konu olabilir. Emtianın sanal olması ise ticari bir mal olmasına engel değildir. Birçok ülkede fiziken mağazalarda satılan, özel tasarımlı madeni para şeklinde içinde özel yazılım ve kodlar bulunan ürünler vasıtası ile bitcoin taşınır bir emtia/mal haline de gelebilir. Bu durumda sanal para her türlü sözleşmeye de konu olabilir (Turhan, 2018). 


\section{3. Dolandırıcılık/ Siber hırsızlık}

Kripto paralarla ilgili önceki bölümde açıklanan hukuki boşluklar ve kripto para sahiplerinin merkezi regülasyonlarla korunmasız kalması bu paraların barındırdığı sanal değerleri internet dolandırıcılığı, hacking vb. suç eylemleri karşısında da savunmasız bırakmaktadır. Kripto paralar dijital olmaları ve kural dışı bir sistemde yer almaları nedeniyle birçok suç faaliyetinin nesnesi olmaktadır (Elliot vd., 2018, s. 25). Başlangıçta sadece mübadele için kullanılan kripto paralar kendine özgü online pazarlarda diğer bilinen ülke paralarına (Amerikan doları, İngiliz Sterlini, Euro, Japon Yeni gibi) kolayca dönüştürülebilmektedir. Ancak bu dönüşüm pazarları ve kripto para dönüşüm işlemleri aslında kendi cüzdanlarında son derece korunaklı olan kripto paraların kolayca çalınmasına ve siber saldırılarla ele geçirilmesine (hacking) sahne olmaktadır (Martucci, 2019).

Hukuki boşluk nedeniyle mal varlığ kapsamına girmeyen bir hakkın (kripto para sahipliği veya işlem yapma hakkı) hırsılılı ya da yağma ile ele geçirilmesinin suç sayılması Nullum Crimens Nulla Poena Sine Lege (Kanunsuz Suç ve Ceza Olmaz) ilkesi gereğince olanaklı değildir (Uyar, 2018). Bu durum birçok ülkede bu tür suçları cezasız bıraktığı için kripto para sahipleri suça karşı hukuken de korumasız kalmaktadır. Aslında mal varlığına karşı bilişim sitemleri kullanılarak işlenen hırsızlık suçları nitelikli sayılıp daha ağır yaptırımlarla cezalandırılmaktadır. Ancak kripto paralar mal varlığı kapsaminda değerlendirilmemektedir (Uyar, 2018).

Uluslararası bir rapora göre kripto para işlemlerinde dolandırıcılık, hırsızlık ve suç konusu ${ }^{5}$ para miktarı 2019 yılında 4.5 milyar dolar, 2020 yılında ise 1.98 milyar dolar olmuştur (Ciphertrace, 2021). Türkiye'de de özellikle kripto paraların diğer dövizlerle işlem gördüğü online pazarlarda çok sayıda suç işlenmektedir (Kartal, 2019). Genellikle siber saldırı/hacklenme yöntemi kullanılarak s1k s1k online kripto para borsalarından hırsılıklar yapılmaktadır (Eser, 2019a; Eser, 2019b). Kripto paralar aynı zamanda dolandırıcılık aktivitelerine de sıklıkla konu olmaktadır. Yaygın bir yöntem olan sahte kripto paraların (scam coin) satışı ve/veya ihracı 2020 yılında yatırımcılardan doland1rılan miktar itibarıyla birinci sıradaki dolandırıcılık yöntemidir (Ciphertrace, 2020). Ayrıca kayıtsız veya lisanssız firmalar kripto paralar üzerinden yüksek getiri garanti ederek sunduğu yatırım planları ile dolandırıcılık amacıyla para toplamaktadır (Elliot vd., 2020, s. 25). Türkiye'de kripto paralarla ilgili 2021 yılında arka arkaya çıkan büyük dolandırıcılıklar yıllardır belirgin bir politi-

5 Birçok örnek olaya ve istatistiğe yer verilen güncel ve ayrıntılı bir rapor için Bkz: (Cipherprice, 2021). 
ka geliştiremeyen otoriteleri kripto para işlemlerini yasaklamaya kadar veren radikal kararlar almaya sevketmiş olup, bu kararlar ve gelişmeler çalışmanın ilerleyen bölümlerinde açıklanmıştır.

\section{4. Kara Para Aklama}

Kripto paraların kullandığı karmaşık ve şifreli protokoller kullanıcıların kimliğini gizlediğinden işlemlerin ve para akışlarının izlenmesi ve bunların öznelerinin belirlenmesini yani hangi kişi veya gruplarca yapıldığının tespitini son derece zorlaştırmaktadır (Martucci, 2019). Kimi kullanıcılar açısindan kripto paraların avantajları arasında sayılan bu durum kripto paraların yasa dışı aktivitelerde bir ödeme/transfer aracı olabilmesine neden olmaktadır (CRS 2018:15). Geleneksel finansal sistemde bu tür aktiviteler müşteri kimliklerinin bilinmesine dair $(K Y C)^{6}$ prosedürler ve para-aklama karşıtı $(A M L$; Anti-money laundering) tedbirler gibi yasal zorunluluklar özellikle bankaları müşteriler hakkında temel bir istihbarat yapmaya ve şüpheli işlemleri takip etmeye sevk etmektedir (Elliot vd, 2018:22).

Türkiye'de de bankacıllk sisteminde müşteri bilgileri ve işlemleri takip edilebilmekte ve MASAK'ın şüpheli işlem bildirimine dair düzenlemeler arac1lığı ile kaynağ 1 ya da nedeni belirsiz işlemler izlenmektedir. Kripto paralar ise bankalar gibi üçüncü bir taraf olmaksızın yapılabilen anonim işlemlerle el değiştirebildiğinden bu tür düzenlemelerden muaftır. Bu nedenle kara para aklama, terörizmin finansmanı, vergi kaçırma gibi yasa dışı aktiviteler için elverişli bir ortam sağlayan kripto paralar, tıpkı nakit para gibi izi sürülemeyen bir enstrüman işlevi görebilmektedir. Türkiye'de kara para aklama ile ilgili işlemleri takip eden başlıca birim olan MASAK'ın kripto paralarla ilgili gündemi çalışmanın aktörlerle ilgili analiz bölümünde açıklanmıştır. MASAK kripto paralarla ilgili işlemleri ancak bu paralar kullanımdaki döviz cinslerine dönüşerek sistemdeki banka hesaplarına aktarıldığında izleyebilmektedir. Kurum bunun için bankaların kullanmak zorunda olduğu şüpheli işlem bildirim formlarını güncellemekle birlikte, banka hesabına gelmeden önce paranın aklanmasına neden olabilecek kripto para dönüşümlerini takip edememektedir.

\subsection{Finansal/spekülatif riskler}

Kripto paraların çoğunluğunun arzı sınırlıdır. Kaynak kodları bütün zamanlarda yaratılabilecek kripto paraların miktarını sınırlamaktadır. Zamanla madenciler tarafından üretilmesi zorlaşan kripto para birimleri belirli bir üst limite ulaşıldığında üretilemez hale gelir (Martucci, 2019). Bu durum kripto

6 KYC, bankalar dahil finansal kurumlar ve iş dünyasının diğer unsurlarında müşterilerin bilgi ve alışkanlıklarının öğrenilmesine ve kayıt alınmasına dair süreçleri ifade eden bir terimdir. 
paraları teorik olarak sonsuz miktarda üretilebilen merkez bankası paralarının aksine enflasyondan korur. Kripto para arzı üzerinde banka ve devletlerin etkisi yoktur. Sisteme dışardan para arzı yapılamaz, arz, başarılı blok oluşturan madencilere verilen ödüller şeklinde ve sınırlıdır (Çarkacıoğlu, 2016, s. 16) $\mathrm{Bu}$ sınırlılık durumu kripto paralarının değerini talebin ve spekülatif hareketlerin belirlemesine neden olmaktadır. Bir başka ifadeyle değer ve sınırlılık bakımından altın veya diğer değerli metallere yaklaşan kripto para değerleri aşırı artabilir. Ancak diğer para birimlerine ve altına oranla daha fazla oynaklığa sahip olan kripto paralar, riskli bir yatırım ve ödeme aracıdır (Koçoğlu vd, 2016, s. 93). En yaygın kripto para birimi olan Bitcoin 2017 yılının başında 993 USD seviyesinden işlem görürken, aynı yılın Aralık ayında 18 kat artarak 19.650 USD seviyesine çıkmış, ancak iki ay içerisinde \%65 azalarak 6.905 USD seviyesine dönmüştür. Bu keskin iniş çıkışlar 2020 yılına kadar süregelmiştir (CRS, 2020:9).

Bir kısım yatırımcıların parlak bir yatırım aracı olarak gördügü kripto paralar için finans sektörü uzmanlarının tamamı saf bir spekülasyon aracından başka bir şey olmadığını düşünmektedir (Martucci, 2019). Bu durumda kripto paraların değerindeki spekülatif hareketler, iniş ve çıkışlar yatırımcıları önemli değer kayıpları ile karşı karşıya bırakabilmektedir. Yatırımcıları koruyacak düzenlemelerin eksikliği, kripto paraların şeffaf olmayan yapısı ve kamu sektörünün hatta finans sektörünün henüz kripto paraları tam olarak tahlil edememiş olması bu kayıpları daha da ileri taşıyabilir (Elliot vd., 2018, s. 16,24). Türkiye'yi ülkeyi dünya istatistiklerinde üst sıralara taşıyacak kadar çok olan kripto para sahiplerinin birçoğunun yatırım amacı güttüğü düşünüldügünde, kullanıcıların bu tür risklere açık olduğu aşikardır.

Daha da önemli diğer bir finansal risk ise kripto paranın istenilen döviz birimine değerinden ve hızlıca dönüşebilmesi anlamına gelen likiditenin gerçekleşememesi riskidir. Türkiye'de de üst üste yaşanan büyük hacimli dolandırıcılık olaylarından sonra devreye alınan önlemlerle yaşanabildiği gibi kripto paraların finansal sistemde alım satımı ve diğer para birimlerine dönüştürecek sistemlerin tasarlanmasının dahi yasaklanması ile likidite riski ortaya çıkmıştır. Alışverişte kullanılamayan veya diğer para birimlerine dönüştürülemeyen kripto para sahibini/ veya yatırımcısını finansal kayıplarla karşı karşıya bırakmaktadır. Martucci de (2019) bu riske dikkat çekerek birçok ülkenin kripto paralara güvenmediğini hatta düpedüz yasa dışı ilan ettiğini belirtmektedir. Son tahlilde kripto paralar finansal olarak yatırımcısını veya sahibini dramatik kayıplara sürükleyecek iki önemli tehlikeyi işaret eden spekülatif değer dalgalanmaları ve likidite riski taşımaktadır. Bu riskler farazi olmayıp bizzat yaşanmış ve yaşanmaktadır. Türkiye' de de TCMB, BDDK, Hazine ve 
Maliye Bakanlığı gibi düzenleyici/denetleyici politika aktörleri çalışmanın üçüncü bölümünde de açıklandığı üzere kamuoyunu bu riskler konusunda siklıkla uyarmaktadır.

\subsection{Maliye/Vergi Sorunları}

Kullanıcıların genellikle yatırım aracı olarak gördüğü kripto paraların değerlerinin iniş çıkışları sırasında, diğer yatırım araçlarına benzer kazançlar sağlanmasına neden olabilmektedir. Bu durum bütün diğer yatırım araçlarından elde edilen kazançları vergilendirmekte olan maliye yönetimlerini kripto para kazançlarını da bu kapsama almaya zorlamaktadır. Türkiye'de kripto paraların alım satımında doğan kazançların vergilendirmesi 2017 yılından bu yana kamu otoritelerinin gündeminde olan bir konudur. Ancak kripto paraların tanımındaki boşluk doğal olarak kazancının tanımlanmasında da hukuki olarak belirsiz bir alan yaratmaktadır. Basına yansıyan bir röportajdan Hazine ve Maliye Bakanlığı'nın ilgili birimi olan Gelir İdaresi Başkanlığı'nın da bu konuda tereddüt ettiği ve 2017 yılında SPK ve Merkez Bankası'na danıştığ 1 anlaşılmaktadır (Ak, 2017). Gelir İdaresi Başkanı'na göre kripto paraya isim verilmesi vergilendirme için ana koşul olup, üç isim üzerinde durulmakta, bunlardan ilkinin Bitcoin'in bir 'emtia' olarak kabul edilmesi, ikincisi 'menkul kıymet' ve üçüncüsü de 'para' olarak adlandırılmasıdır'. Aynı haberde menkul kıymetin dayalı olduğu gerçek bir ürün olmadığı için SPK, Bitcoin'in kendi menkul kıymet tanımına uymadığını belirtmektedir.” (Ak, 2017).

Karşı1laştırmalı bir değerleme sonrasında ortaya atılan bir görüşe göre, kripto para geliri, vergiye tabi tutulursa, hükümetlerin kripto paralara karş1 olmaları da beklenmez. Brezilya, Kanada, Finlandiya, Bulgaristan ve Danimarka gibi ülkeler kripto para kullanımının vergilendirilmesi konusunda düzenlemeler yapmışlardır, bazı ülkeler ise varlık veya ürün olarak gördüğ̈ kripto paralarla yapılan alışverişlerden KDV almaktadır (Çarkacıoğlu, 2016, s. 56). Türkiye'de ise kripto paraların vergilendirmesinde temel sorun tam olarak buradadır, Türkiye kripto paraları henüz bir varlık veya ürün olarak çerçevelendirmemiştir. Bununla birlikte kripto paraların vergilendirilmesi konusu Cumhurbaşkanlığı'nın ekonomik program paketlerine kadar dahil edilmiştir. Bu konuda yapılan detaylı bir mütalaaya göre takas platformları aracılığı ile alım satım yapan kullanıcıların nasıl vergilendirileceği sorunu doğrudan kamu otoritelerinin yapacağı kripto tanımına bağlıdır. Kripto paraların menkul kıymet veya diğer sermaye piyasası aracı olarak tanımlanması, değer artış kazan-

7 Gelir İdaresi Başkanı ağırlık kazanan görüşe göre kripto paraların emtia sayılması halinde satışından bir kez kazanılan gelirin değer artı̧ kazancı veya arizi kazanç olarak; sürekli alım satından elde edilen kazançların ise gelir olarak vergilendirileceğini belirtmektedir. (Ak, 2017) 
cı olarak vergilendirilmesini; emtia olarak tanımlanması ise ticari kazanç olarak vergilendirmesini gerektirmektedir (Ak, 2017). Para olarak tanımlanması durumunda ise döviz olarak mütalaa edileceğinden vergiye tabi olmayacaktır. Özetle, kripto paranın tanımı ile ilgili belirsizlik vergilendirilmesine dair yürütülen fikirleri bile karmaş1k hale getirmektedir.

\section{Türkiye'de Kripto Paraların Politika Gündemine Alınması: Aktörler ve Tutumlar}

Politika sorunu kavramının açıklandığı bölümde de belirtildiği üzere kamu politikalarının analizinde kullanılan politika döngüsü modelinin ilk aşaması sorunun tanımlanması ve politika yapanların gündemine alınmasıdır Ancak her politika sorununun gündeme alınması söz konusu değildir. Hayese göre genellikle kriz aşamasına gelmeden politika sorunları ihmal edilmektedir (1992:3). Bir başka görüş ise gündemin belirlenmesi aşamasını problemler ve konuların elendiği bir süzme sürecinin sonucuna benzetmektedir. Bu süreç gündeme alın(a)mayan sorunlar hakkında karar vermeme (non-decision) ile sonuçlanır (Jahn ve Wegrich, 2007:46). Bir sorunu karar vermeyerek, askıda bırakan gündeme alınmama durumunun birçok nedeni olabilir. Politika yapicilar gerekli kapasiteye sahip olmayabilirler veya siyasilerin ya da bürokratların kendi öncelik ve ajandaları olabilir (Bardach ve Patashnik, 2016, s. $3)$. Bu konuda politika üretilmesini isteyen veya istemeyenler arasında, ya da sorunun şiddetini ve önemini farklı algılayanlar arasında çekişme veya görüş ayrılığ 1 da olabilir. Hayes' e göre bir politika sorunu hakkında ciddi bir tedbir alınması gerekip gerekmediği konusunda farklı aktörlerin sorun hakkında çatışan algı ve çıkarlarınca yaratılan tipik bir çekişme vardır. Politika yapıcıların sahip oldukları sınırlı zaman ve ilgi problemin ajandaya alınmasını güçleştirir ve hangi meselelerin öncelikle ciddiye alınacağ 1 hakkında toplumun değerleri ve algıları ile birlikte bu çekişme de belirleyici olur (Hayes, 1992, s.2). Özetle bir sorunun gerçek anlamda gündeme alınması için politika yapıcıların kurumsal ajandasına taşınması, tüm aktörler tarafından ciddi bir tehdit olarak algılanması ve acilen çözülmesi gerektiği yönünde bir görüş mutabakatı olması gerekmektedir. Türkiye'de kripto paraların kamu politikalarında bu görüşleri doğrulayan şekilde gündeme taşındığı, gündemde askıda kaldığı ve/ veya eksik taşındığı bir serüven yaşanmıştır.

Kripto paralar daha çok elektronik para ile ilgili düzenlemeler sırasında gündeme gelmiştir. Aşağıda da açıklanacağ 1 üzere elektronik para olarak da tanımlanmayan kripto paralar hukuki düzenlemelerden dışlanmış, hakkında kamuoyunun sadece riskleri hakkında bilgilendirilip, politika kararı verilmediği sıradan bir gündem maddesi olmuştur. Kripto paranın yine zayıf olarak 
gündeme taşındığı bir başka durum ise merkez bankasının kendi kripto parasını yapacağı yönündeki haber ve açıklamalar olmuştur. Kripto para ancak büyük çapta dolandırıcılıkların yapılması ile gerçek anlamda tehdit olarak algilandığında, yani önceden duyurulmakla yetinilen riskler 2021 y1lında gerçekleştiğinde, acil bir sorun olarak gündeme alınmıştır. Hızlı bir politika süreci sonrasında yasaklamaya varan önlemlerle finansal sistem dişına itilmiştir.

Türkiye'de yaygın kullanımına ve bir önceki bölümde açıklanan çeşitli ve karmaşık politika sorunlarına rağmen 2021 yılının ikinci çeyreğine kadar izlenen belirgin ve kararlı bir kripto para politikasının varlığından söz etmek zordur. Kamuoyunda kripto para kullanımına dair sorunların sıklıkla tartışılmasına rağmen, böyle bir politikanın eksikliğinin temel nedeni sorunun gündeme bütün yönleriyle ve kararlılıkla alınmamış olmamasıdır. Tutarlı ve kapsamlı bir kamu politikası belirlenmemesinin diğer başlıca nedeni ise eşgüdüm içinde hareket edemediği anlaşılan aktörlerin çokluğudur. Kripto paraların beraberinde getirdiği politika sorunlarının çeşitliliği ve çok yönlü özellikleri politika aktörlerinin kamu sektörü tarafındaki sayısı ve çeşitliliğini artırmaktadır. Kripto paraların ödeme sistemi olma özelliği; bankalar arası ve uluslararası ödemeler sistemini koordine eden TCMB ile ödeme ve elektronik para kuruluşlarını düzenleyip denetleyen BDDK'nu politika aktörü konumuna sokmaktadır. Bir yatırım aracı olma özelliği ise kripto paraların SPK politikalarının ve regülasyonlarının bir nesnesi olması gerekliliğini beraberinde getirmektedir. Kripto paraların alım satımından doğacak kazançların vergilendirilmesi veya kara para aklaması gibi illegal faaliyetlerde kullanılma ihtimali de, Hazine ve Maliye Bakanlığı'nı ve kurulu olan MASAK'1 da önemli birer politika aktörü yapmaktadır. Aslında ekonomi ile ilgili olarak bütün kamu politikalarının ve aktörlerinin koordinasyonundan sorumlu Cumhurbaşkanlığının yönetici ve karar verici baskınlığ da kurumu başlıca politika aktörü konumuna taşımaktadır. Tablo 2'de bu aktörlerin 2013-2021 yılları arasındaki dönemde kripto paralarla ilgili gündem konuları, gündeme alma nedenleri ve aldıkları politika kararları özet olarak sunulmuştur. 
Tablo 2. Türkive'de Kripto Para Politikalarının Gündem İzlencesi

\begin{tabular}{|c|c|c|c|}
\hline Politika Aktörü & Gündem Dönemi & Gündeme Alınıs Nedeni & Üretilen Politika/Politika Karar1 \\
\hline \multirow[t]{3}{*}{ BDDK } & 2013 & 6493 s. Elektronik Para Kanunu & Kripto paraların kapsam dıș tutulmas1 \\
\hline & 2019 & Güncel Gelișmeler & Kripto paraların kapsam dișı tutulması \\
\hline & 2019 & Güncel Gelismeler & Kripto paraların güvencesiz olduğunun açılanması \\
\hline \multirow[t]{3}{*}{ TCMB } & 2017 & Güncel Gelişmeler & BDDK açıklamalarının tekrar edilmesi \\
\hline & 2021 & Ekonomi Reformu Eylem Planı & $\begin{array}{l}\text { Dijital para altyapı çalş̧maları sorumluluğunun } \\
\text { bankaya verilmesi }\end{array}$ \\
\hline & 2021 & Dolandirıcilk faaliyetleri & $\begin{array}{l}\text { Kripto para isslemlerinini finansal sistem dahilinde } \\
\text { yasaklanması }\end{array}$ \\
\hline Finansal İstikrar Komitesi & 2018 & Güncel Gelișmeler & Çalıșma grubu olușturulmas//kamuoyu uyarıları \\
\hline \multirow[t]{2}{*}{ MASAK } & 2014 & Güncel ve Uluslararası Gelişmeler & $\begin{array}{l}\text { Bütün kripto para işlemlerinin Şüpheli İşlem } \\
\text { Bildirimlerine eklenmesi }\end{array}$ \\
\hline & 2019 & Güncel ve Uluslararası Gelişmeler & $\begin{array}{l}\text { Uyumsuz kripto para işlemlerinin Şüpheli İşlem } \\
\text { Bildirimlerine eklenmesi }\end{array}$ \\
\hline \multirow[t]{2}{*}{ SPK } & 2017 & TSPB Talebi & Hukuki bosluk kararı ve islem yapılmaması uyarı1 \\
\hline & 2018 & Güncel Gelişmeler & $\begin{array}{l}\text { Kripto para ihracı (ICO) ile fonlamanın uygun } \\
\text { olmadığııı duyurulması }\end{array}$ \\
\hline \multirow[t]{4}{*}{ Cumhurbaşkanlı̆̆ } & 2019 & 11. Kalkınma Planı & $\begin{array}{l}\text { Anlık Ödeme Sistemi ve dijital TCMB parası } \\
\text { üretilmesinin planlanması }\end{array}$ \\
\hline & 2019 & Cumhurbaşkanlığı Ylllık Programı & 6493 sayılı kanunun değiştirilmesi \\
\hline & 2019 & Yeni Ekonomi Programı & $\begin{array}{l}\text { Kripto paraların vergilendirmesi ve suçun } \\
\text { finansmanında kullanımını önlenmesini planlanmsa1 }\end{array}$ \\
\hline & 2021 & Ekonomi Reformu Eylem Planı & $\begin{array}{l}\text { TCMB^nin dijital para altyapısı ile ilgili } \\
\text { görevlendirilmesi }\end{array}$ \\
\hline
\end{tabular}

Tablo 2'de de görüldüğü üzere kripto paraların politika gündemine sıklıkla taşındığ dönem son üç yılda yoğunlaşmış olup, güncel gelişmelerle tetiklenmiştir. Alınan politika kararları icrai olmaktan çok kamuoyu bilgilendirmeleri ve planlamalarla sinırlıdır. Bunun istisnası 2021 yılında TCMB'nin aldığ 1 ve kripto para işlemlerini finans dünyasından dışlayan yasaklama kararları olmuştur. Tabloda özetlenen kamu politikası aktörleri, gündem ve tutumları aşağıdaki alt başlıklarda ayrıntılı olarak açıklanmıştır.

\subsection{BDDK: Kripto para, elektronik para değildir!}

Kripto para internetin ve finans teknolojilerindeki gelişmelerin ortak ve kaçınılmaz bir para benzeri ürünüdür. Para tanımı ve kullanımında kredi kartı ile başlayan gelişmelerle beraber, nakit kullanımının terkedilmesiyle başlayan değişim süreci elektronik para kavramı ile özellikle 2000'li yıllarda yeni bir döneme girmiştir. BIS'in (Bank of International Settlements) genel tanımına göre elektronik para, tüketiciye küçük meblağl1 işlemler yapmasına izin veren çip veya smart card bazlı elektronik cüzdan veya kartlar veya yazılım temelli internet şebekeleridir (2011, s. 1-2). BIS'e göre (2011, s. 85) 2001 yılında Türkiye'de sadece çipli kartlarla ilgili birkaç proje ve bazı belediyelerdeki akıllı kartlar dışında bir uygulama veya bu konuda politika belirleyen bir merci bulunmamaktadır. Bu ürünler de BIS'in çok amaçlı ve genel kullanıma uygun elektronik para tanımı kapsamının dışındadır. Ancak zamanla elektronik para kullanımının yaygınlaştığı Türkiye bu konuyu 2013 yılında gecikmeli bir şekilde kamu politikası gündemine alarak, ilk politika uyarlamasını yapmış ve 
6493 sayılı ödeme ve elektronik para kuruluşları hakkındaki kanunu çıkarmıştır. Kripto paralarla ilgili ilk resmi açıklama da bu kanundan sonra yapılmıştır. BDDK (2013) elektronik para ile ilgili 6493 sayılı kanuna atıfta bulunarak Bitcoin' $i$ “"herhangi bir resmi ya da özel kuruluş tarafindan ihraç edilmeyen ve karşıllğ̆ için güvence verilmeyen bir sanal para birimi" olarak tanımlamıştır. Aynı açıklamanın devamında Bitcoin'in mevcut yapısı ve işleyişi itibarıyla kanun kapsamında elektronik para olarak değerlendirilmediği ve dolayısı ile gözetim ve denetiminin mümkün olmadığı belirtilmiştir. Daha sonra Bitcoin'in ve diğer sanal paraların riskleri; yasadışı faaliyetlerde kullanılması, piyasa değerinin aşırı oynak olabilmesi, dijital cüzdanların çalınabilmesi, kaybolabilmesi veya sahiplerinin bilgileri dışında usulsüz olarak kullanılabilmesi, işlemlerin geri döndürülemez olmasından dolayı operasyonel hatalardan ya da kötü niyetli satıcıların suiistimalinden kaynaklı risklere açık olması olarak sıralanarak kamuoyu uyarılmıştır. (BDDK, 2013).

Aslında kripto para halen ilk doğuş amacına uygun olarak mübadele işlemlerinde de kullanılabildiği için elektronik para kapsamında sayılabilir. Bu durumda kripto paraların 6493 sayılı kanuna ve buna bağlı olan BDDK tarafından çıkarılan yönetmelik ve tebliğe tabi olması gerektiği sonucu ortaya çıkmaktadır (BDDK,2014a; 2014b). Ancak söz konusu kanun, hem ödeme sistemlerini, hem de elektronik para ihracatı yapılmasını minimum sermaye, açık ve şeffaf şirket yapısı, BDDK'nın faaliyet izni ve ticari bankalarla çalışma yükümlülüğü gibi birçok şarta bağlamaktadır (6493 s. K., md.12-20). Kripto paraların ve sistemlerinin doğası gereği bu düzenlemelere uyması imkansızdır. Bu imkânsızlık BDDK'nın kripto paraları sistem dışı ilan etmesine yol açmıştır. Kurumun bir başka tanımına göre "Bitcoin herhangi bir resmi ya da özel kuruluş tarafindan ihraç edilmeyen ve karş1lı̆̆ 1 için güvence verilmeyen bir sanal para birimi olarak" bilinmektedir (BDDK, 2019a). BDDK (2019a) ayrıca Bitcoin'i mevcut yapısı ve işleyişi itibarıyla kanun kapsamında elektronik para olarak değerlendirmediğini tekrar vurgulamıştır.

\subsection{TCMB: Kripto para para değildir!}

TCMB açısından kripto para iki temel alanda sorun teşkil etmektedir. Birincisi değerini korumakla sorumlu olduğu ulusal para birimine alternatif oluşturabilme olasılı̆̆ alanına giren ödeme sistemi aracı olarak kripto paraların yasal olarak tanımlanmamasının yarattığı yukarıda açıklanan hukuki belirsizlik. Başlangıçta

8 Açıklamanın yapıldığı tarihte bitcoin sanal para piyasalarında bilinirliği ve yaygınlığı açısından neredeyse tek para birimidir. Bu durum o dönemki resmi duyurulara da yansımış ve zaman zaman "bitcoin" tabirinin sanal para kavramı ile eş anlamlı olarak kullanılmasına neden olmuştur. 
internet üzerinden aracısız, düşük maliyetli ve güvenli transfer amacıyla geliştirilen kripto paralar bugün merkez bankalarının para otoritesi olma geleneğinin/itibarının sorgulanmasına ve para tanımının gözden geçirilmesine neden olmaktadır.

Öte yandan, ödeme ve menkul kıymet mutabakat sistemleri alanı da, tıpkı para politikası, finansal istikrar, para basma gibi temel merkez bankac1lı̆̆ faaliyetlerinden biri olup TCMB'nin görev ve yetki alanındadır. TCMB Kanunu çerçevesinde, "ödeme ve menkul kıymet transferi ve mutabakat sistemleri kurmak, kurulmuş ve kurulacak sistemlerin kesintisiz işlemesini ve gözetimini sağlamak ve gereken düzenlemeleri yapmak, ödemeler için elektronik ortam da dâhil olmak üzere kullanılacak yöntemleri ve araçları belirlemek" bankanın temel görevleri arasındadır (1211 s. K., md.4/f). Ayrica 6493 sayılı kanuna göre de $(2013, \mathrm{~m} .3 / \mathrm{j})$ ödeme ve menkul kıymet mutabakat sistemlerine faaliyet izni verme, ikincil düzenlemeler çıkarma ve gözetim yapma görev ve yetkisi TCMB'dedir. TCMB aynı zamanda TCMB Ödeme Sistemlerinin kurucusu, sahibi, işleticisi ve gözetim sorumlusudur (TCMB, 2019, m. 6). Dolayısı ile bir ödeme aracı olarak kripto paraların tanınıp tanınmaması ve ödeme sistemlerine dahil edilmesi hususları yasal olarak TCMB'nin yetki alanındadır.

Bununla birlikte aslında BDDK'ndan daha etkin ve yetkili olması beklenen TCMB'nin sanal paralar hakkındaki resmi görüşü BDDK görüşüne atıf yapmakta ve kurumun Bitcoin'in herhangi resmi veya özel kuruluş tarafından ihraç edilmediği ve karşıllğı için güvence verilmediği yönündeki tespitini yinelemektedir (TCMB, 2017). Bankanın uzmanlarının paranın bir devletin merkez bankası tarafından ve yine fiktif de olsa bir değer karşılığında basılmış olması gerektiğinden yola çıkarak, kripto paraların para sayılamayacă̆ını savunduğu da bilinmektedir (Ak, 2017). Aslında bu görüşe uygun olarak bankaya 2021 yılı sonuna kadar kendi dijital/kripto parasını çıkarması görevi de verilmiştir (Hazine ve Maliye Bakanlığı, 2021, m.3, 4.d) Resmi bir duyuru yapılmamış olsa da, yerli kripto paralar ile ilgili test aşamasında çalışmalar ${ }^{9}$ başlatıldığı ileri sürülmektedir (Yardımc1, 2021).

Sonuçta, yasalarda kripto paralara açıkça yer verilmemesi, TCMB ve BDDK'nin kripto parayla ilgili politikalarını kendi sorumluluk alanlarıyla koşut olarak paranın genel fonksiyonları açısından ve ödeme sistemleri üzerinden kurgulamalarında sorun yaşamasına neden olmuştur. Türkiye'de krip-

9 Basına yansıyan bazı gelişmelere göre Merkez Bankası, Ticaret Bakanlığı ile birlikte kripto paralarla ilgili test çalışmalarına başlamış olup, testlerin başarı durumuna göre Türkiye kendi ürettiği dijital parasını kullanıma sokabilecektir (Yardımc1, 2021) 
to paraları ve bunların kullanımını düzenleyen müstakil bir yasanın yokluğu hukuki normlar hiyerarşisi açısından bu konuda bağlayıcı bir yönetmelik veya alt düzenleme çıkarılmasını da olanaksız kılmaktadır. Bir başka deyişle, TCMB ve BDDK'nin sahip olduğu hukuki düzenleme yapma kapasitesi ancak yasa koyucunun bu konuda çıkardığı/çıkaracağı yasalarla sınırlıdır ve böyle bir yasanın olmamasının yarattığı hukuki boşluk politika formülasyonu ve uyarlaması aşamalarında kurumları etkisiz kılmaktadır. TCMB'nin kripto paralarla ilgili son tutumu ise 2021 yılının ilk çeyreğinin sonunda kripto para platformlarında yaşanan büyük meblağlı dolandırıcılık olaylarından sonra aldığı yasaklama kararı olmuştur. Şimdiye kadar Türkiye'de bir politika aktörü tarafından alınan en önemli yürütme aksiyonu olan bu yeni kararın sonuçları ile birlikte değerlendirilmesi için erken olmakla beraber bu karar ve karara neden olan gelişmeler bölümün son alt başlığında açıklanmıştır.

\subsection{Hazine ve Maliye Bakanlığı}

Hazine ve Maliye Bakanlığı kripto paralarla ilgili olarak politika gündemini belirleme yetkisi olan (Cumhurbaşkanlığı haricinde) tek hükümet unsurudur. Türkiye'de yürütme erkinin önemli unsurlarından biri olan bakanlık yine de bu gücünü kullanıp aksiyon almaktan çok bağlı komite ve kurumları ile kamuoyu bilgilendirmesi yönünde pasif politika karar ve tutumları ile yetinmiştir. Bakanlık kripto paranın berberinde getirdiği finansal risklerle ilişkili olarak Finansal İstikrar Komitesi, kara para aklama/terörün finansmanı ile ilgili politika sorunlarını ise MASAK aracılığı ile analiz takip etmektedir.

\subsubsection{Finansal İstikrar Komitesi (FİK)}

Ekonomi Bakanlığı'na bağlı olarak ihdas edilmişken, Hazine ve Maliye Bakanlığı'na devredilerek adı da değiştirilen ${ }^{10}$ Finansal İstikrar Komitesi (2018) yasal bir dayanağı olmayan kripto paralara ilişkin düzenlemelerin geliştirilmesi için bir çalışma grubunun oluşturulmasına karar verildiğini açıklamıştır. Komitenin kuruluş kanununda sayılan sistemik risk yönetimi, finansal düzenlemelerde ve uygulamalarda uyumun sağlanması görevlerine uygun olarak konuyu gündemine alması doğaldır (4059 s. K., md.1). Komite diğer otoritelerin yaptığı uyarıları tekrarlayarak "kripto paralar kapsamında gerçekleştirilen işlemler herhangi bir resmi otoritenin güvencesi altında olmadığını" belirtmiştir (Akyıl, 2018). Ancak bu açıklamanın BDDK veya SPK'nın uyarılarından daha detaylı olduğu ve kripto para işlemleri ile ilgili risklerin kap-

10 Komite mülga Hazine ve Dış Ticaret Müsteşarlıklarının tam olarak icrai olmayan veri toplama, koordinasyon, risk yönetimi gibi işlevlerinin 2018 yılında devredildiği bir danışma yapısına dönüştürülmüştür (4059 S. Kanun, md. 1). Komitenin adı 2019 yılında Finansal İstikrar ve Kalkınma Komitesi olarak değiştirilmiştir (7161 S. Kanun). 
samlı bir biçimde sıralanması ve sermaye toplamak için yapılan yeni dijital para ihracından (ICO işlemleri/Initial Coin Offering) kaynaklanan riskleri de ihtiva etmesi açısından dikkat çekicidir.

Finansal İstikrar Komitesi rapor formatında detaylı bir basın açıklamasında kripto paralardan kaynaklanan riskleri; (1) piyasa değerinin aşırı oynak olabilmesi; (2) dijital cüzdanların çalınabilmesi, kaybolabilmesi veya sahiplerinin bilgileri dışında usulsüz olarak kullanılabilmesi; (3) kullanıcıların ve hizmet alınan firmaların operasyonel hatalarından ya da kötü niyetli kişilerin suiistimallerinden kaynaklanan zararların telafisinin olmaması; (4) kripto paraya dayalı bazı iş modellerinin, büyük kârlar vadeden oluşumlar şeklinde yapılanarak kişilerin bilgi eksikliğini suiistimal etmesi ve önemli maddi kayıplara neden olabilmesi; (5) kripto para ihraç edecek girişimlerin dolandırıcılığa için uygun bir zemin oluşturması; (6) kripto paranın dolaşımda olduğu piyasanın herhangi bir resmi otorite ya da garantör kurum tarafından denetlenme imkanı olmadığından, yasadışı faaliyetlerde de kullanılabilmesi olarak sıralanmıştır (FIK, 2018). Komitenin bu tarihten sonra kripto paralarla ilgili kendi kanallarından duyurduğu veya basına açıkladığı bir çalışmasına rastlanılmamış olup, kripto para sorununa dair bahsedilen risk uyarıları ile yetinmiştir.

\subsubsection{Mali Suçlar Araştırma Kurulu (MASAK): Kripto para işlemleri şüphelidir}

Türkiye'de kara para aklama dahil, mali suçlarla ilgisi olabilecek şüpheli işlemlerin izlenip araştırılmasından sorumlu bir bakanlık kurulu olan MASAK, başlangıçta her türlü kripto para işlemini şüpheli olarak değerlendirmiştir. Kurumun üye olduğu uluslararası grupların sanal para kullanımının neden olduğu aklama ve terörün finansmanı zayıflıkları konusundaki araştırmalarına katkı sağladığı bilinmektedir (MASAK, 2015, s. 50). Kurum kripto paranın kara para aklamadaki uluslararası rolü ve risklerinden haberdar olma durumu ihtiyatlı ve kuşkulu yaklaşımını pekiştirmiş, bu yaklaşım denetim faaliyetlerine de doğrudan yansımıştır. MASAK'ın 2014 yılında yayınladığ Türkiye'deki bütün bankalar için bağlayıcı olan Şüpheli İşlem Bildirim (ŞiB) Rehberinde "müşteri hesaplarından Bitcoin satan aracı kuruluşlara Bitcoin al1mına yönelik para transferi yapılması" bildirilmesi gereken şüpheli işlemler arasında sayılmıştır (MASAK, 2014, s. 22).

Ancak Kurumun 2014 yılındaki katı yaklaşımı 2019 yılında değişmiş ve "kripto para alımı amacıyla müşteri profiline uymayacak sıklık ve tutarda para transferi yapılması veya kripto para satımı sonucunda gelen benzeri uyumsuzlukta gelen transferler şüpheli sayılmıştır. (MASAK 2019, s. 25-26). MASAK'ın bu düzenlemesi kripto paralarla ilgili basına yansıyan haberlerde 
"standart bir kripto para yatırımcısı için artık para transferinde endişe edecek bir durum olmadığı", "kripto paralar konusunda umut verici bir gelişme olduğu" ve "regülasyon konusunda olumlu bir hamle yapıldığı" şeklinde değerlendirilmiştir (Aydoğan, 2019; Kripto Para Türkiye, 2019; Donanım Haber, 2019). Ancak bu yumuşamanın Türkiye'yi dünya sıralamalarına sokan işlem ve kullanıcı adetlerinin bankaları kripto para işlemleri ile ilgili şüpheli işlem bildirimlerinin sayısı ile ilgili olarak zor durumda bırakmasından kaynaklanması olasidir ${ }^{11}$.

\subsection{SPK ve Kripto Paralar: Kendisi Yok ki, Türevi Olsun!}

Sermaye Piyasası Kurulu 1981 yılında sermaye piyasalarını düzenlemek için kurulmuş olmakla beraber 2012 yılında yeni bir kanunla baştan ihdas edilmiş özerk bir düzenleme ve gözetim kuruludur (6362 s. Kanun). Kurulun kripto para politikaları ile ilgisi kripto paralarla ilgili türev yatırım araçları ve kripto para ihracı gibi kripto para tarihçesinde bile yeni sayılabilecek gelişmelere dayanmaktadır. Kamu kurumu niteliğinde bir meslek kuruluşu olan ve yatırım kurumlarının çatısı altında toplanmış olduğu TSPB (Türkiye Sermaye Piyasaları Birliği) kripto paralarla ilgili yasal düzenlemelerin eksikliği karşısında bu gelişmeler karşısında 2017 y1lı ve sonrasında tereddüde düştüğü ve düzenleyici otorite olan SPK'dan dönem dönem görüş sorduğu anlaş1lmaktadır. SPK'nın (2017) görüş taleplerine cevaben TSPB'ne hitaben yazd1ğ bildirimde sanal paralarla ilgili ülkemizde bir düzenleme veya tanımlama bulunmadığ1 vurgulanmış ve sanal para birimlerine dayalı spot veya türev işlem yapılmaması gerektiğini bildirmiştir. Bu açıklamanın nedeni muhtemelen ABD'de kripto paraya dayalı vadeli işlemlerin başlaması ve yerli aracı kurumların bu işlem ve ürünleri sunmak ve aracılık etmek için görüş sormuş olmasıdır (Turhan,2018). Yani kurum henüz sanal paraların tanımı dahi yapılmadan sermaye piyasalarındaki daha ileri gelişmeler karşısındaki sorular karşısında çaresiz kalmaktadır.

SPK, kitle fonlaması adı altında yapılan dijital varlık satışları ve/veya yeni kripto para ihraçları (Initial Coin Offering) konusunda da bir uyarıda bulunmuş ve "Kripto Para Satışı" veya "Token Satışı" olarak da bilinen genellikle blok-zincir teknolojisi kullanarak para toplamaya yönelik uygulamaların birçoğunun kurulun "düzenleme ve gözetim alanı dışında kalmakta" olduğunu duyurmuş̧tur. (SPK 2018, s. 4). SPK (2019) kitle fonlaması ile ilgili düzenlemesinde de dijital para ihracı ile fonlamaya izin vermemiştir. Bayar (2019), bu düzenlemeyi dijital para birimlerinin Sermaye Piyasası Mevzuatı kapsamında

11 Bakanlığa göre elektronik şüpheli işlem bildirimi uygulamasının yaygınlaştırılması neticesinde şüpheli işlem bildirim sayısı 2019 yılında 203.786'ya ulaşmıştır (Hazine ve Maliye Bakanlığı, 2020:80) 
tanımlanmamasına ek olarak, kripto paraların SPK tarafindan menkul kıymet veya sermaye piyasası araçları arasında da kabul edilmemesi olarak yorumlamaktadır. Özetle kripto paraların yasal düzlemdeki belirsiz durumu SPK'nu da sorumlu olduğu piyasalardaki kripto türevleri ve yeni kripto para ihraçları gibi gelişmeler karşısında politika kararı alamama durumu ile karşı karşıya birakmaktadır.

\subsection{Cumhurbaşkanlığı: Dijital TCMB Parası Geliştirilmesi Planları}

Türkiye'de 2018 yılında geçilen Cumhurbaşkanlığı hükümet sistemi ile birlikte yürütmenin en güçlü unsuru haline gelen Cumhurbaşkanlığı bugüne kadar kripto paralarla ilgili icrai bir işlem yapmamakla beraber planlama aşamasında politika kararları almıştır. Kararlar açıklanan ekonomik tedbir programlarının tali unsurları arasında yayınlanan yerli dijital para geliştirilmesi yönünde olmuştur.

Merkez bankası dijital parası üretilmesi projesi öncelikle 11. Kalkınma Planına alınmış ve Mali Piyasalar Politika ve Tedbirler başlığında yer almıştır (Cumhurbaşkanlığ1, 2019a, s. 41). Böylece dijital/kripto para üretilmesi konusu politika gündemine resmen alınmış olup, politika formülasyonu için de çalışmalar başlamıştır. Bu konu kalkınma planı ile uyumlu hazırlanan Cumhurbaşkanlığı Yıllık Programında da aynen yer almış, "Tedbir 249.5" başl1ğında blok zincir tabanlı dijital merkez bankası parası uygulamaya koyacak kuruluşlar ise TCMB sorumluluğunda olmak üzere TCMB ve TUBİTAK olarak belirlenmiştir. Yapılacak ilk faaliyet ise Anlık Ödeme Sistemi'nin tasarım ve geliştirme aşamalarının tamamlanarak test çalışmalarına başlanması olarak belirtilmiştir. (Cumhurbaşkanlığı, 2019b, md. 250.3). Ayrıca kripto paraları ilgilendirebilecek tedbirler arasında 6493 sayılı kanunun değiştirilmesi ve ödeme sistemlerinin TCMB'ne bağlanması ile Finans Teknopark kurulması da planlanmaktadır (Cumhurbaşkanlığı 2019b, md. 250.4 ve 250.5). Cumhurbaşkanlığı'nın (2020) kripto paralarla ilgili başka bir planı ise sanal varlık işlemlerinin vergilendirilmesi ve bir takip mekanizması kurularak sanal varlıkların suçun finansmanında kullanılmasının önlenmesidir. Kurum ayrıca Dijital Dönüşüm Ofisi aracılığı ile 2021 yılında tamamlanacağ 1 öngörüsü ile hazırlanan Ekonomi Reformu Eylem Planı'nda Merkez Bankası'na verilen yerli dijital paranın alt yapısının oluşturulması eyleminde de gözetim görevini üstlenmiştir (Hazine ve Maliye Bakanlığ1, 2021, md. 3.4.d). Bununla beraber 2019 ve 2020 yılında kripto paralarla ilgili başlatılacağı açıklanan çok yönlü projelerinin planlama veya başlangıç aşamasında kaldığı ve 6493 sayılı kanunda henüz değişiklik yapılmadığı görülmektedir. 


\subsection{Kripto Para Politikalarında Son Durum: Dolaylı Yasaklama}

Yukarıda da belirtildiği gibi dramatik bir ivmeyle hızlanan kripto para transfer ve işlemleri karşısında yapılan son kamu politikası hamlesi, yurt içinde bu işlemleri neredeyse illegal olarak tanımlayan "Ödemelerde Kripto Varlıkların Kullanılmamasına Dair Yönetmelik" adı altında bir TCMB yönetmeliğinin yayımlanması olmuştur (TCMB, 2021). Yönetmeliğin yayınlanmasının temel nedeni ise 2021 y1lı Nisan ayında kripto paranın resmi olmayan borsa aktörlerinden en büyükleri olan aracı platformlarda yaşanan dolandırıcılık ve krizler olmuştur.

Türkiye'nin 391.000 aktif kullanıcısı olan en büyük üçüncü kripto para borsası sahibinin borsasını kapatarak 2-10 milyar USD arasında tahmin edilen bir tutarla beraber yurtdışına kaçması, hemen ardından, bir başka kripto para platformunun finansal zorlukları gerekçe göstererek faaliyetlerini durdurması ve sahibinin göz altına alınması kamuoyunda büyük tepki çekmiştir (Taşçı, 2021; Milliyet, 2021). Son olarak yurtdışı merkezli olmakla beraber ağırlıklı olarak Türkiye'de aracılık yapan bir platform daha işlemlerin, geçici olarak durdurduğunu bildirmiştir (Vatan, 2021).

Arka arkaya yaşanan ve çok sayıda kullanıcıyı mağdur eden bu gelişmeler üzerine hızla çıkarılan söz konusu yönetmelikte adından da anlaşılacağı üzere kripto varlıkların, ödemelerde doğrudan veya dolaylı şekilde kullanılamayacağ1 ve bu konularda hizmet de sunulamayacağı hükme bağlanmıştır (TCMB, 2021, md. 3). Ayrıca TCMB (2021, md. 4/1) bu yönetmeliğinde elektronik para ve diğer ödeme hizmetleri ile kripto para arsında keskin bir sınır çizilerek, bankalar başta olmak üzere finans sektörünün bütün aktörlerine iş modelleri geliştirmeyi dahi yasaklamıştır. Ayrıca kripto para alım/satımı, saklama, transfer ve ihraç hizmeti sunan platformlara aracılık edilmesini veya fon aktarımını da yasaklayarak Türkiye' de kripto varlıklara dair her türlü işlemi mevcut finansal sistemin tamamen dişına itmiştir (TCMB, 2021, md.4/2). Böylece Türkiye'de kripto para işlemleri oldukça geç bir kararla belirsiz ve regüle edilmemiş alandan çıkmış ve dolaylı olarak yasa dışı ilan edilmiştir. Bu yasa dışılığın yönetmelikle değil de, belki kanunla düzenlenmesinin daha güçlü bir politika uyarlama yöntemi olacağ 1 ileri sürülebilir. Ancak elektronik ve dijital ödeme işlem ve enstrümanları düzenlemeleri başından beri yönetmelikle düzenlenmekte olduğundan, hukuki bir teamül izlenmiş olması da mümkündür.

\section{Karşılaştırmalı Kripto Para Politikaları: Dünya Ne Yapıyor?}

Kamu politikası transferi sorunun aynı ya da benzer olduğu durumlarda başvurulan bir enstrüman olup, kripto para politikaları konusunda karşılaştır- 
malı politikada yararlanılması doğaldır. Kripto paralar ve bunlarla ilgili işlemler merkezsiz ve anonim yapısı nedeni ile tüm dünya ülkeleri için benzer sorunlar üretmekte olup, bu sorunlar çalışmanın birinci bölümünde açıklanmıştır. Ancak bu sorunlar için diğer ülkelerde farklı politika çözümleri üretilmiş olup, bazı ülkelerin kripto paralara izin veren hatta bazı uç durumlarda ülke parasıyla eş tutacak kadar liberal politikalar izlediği, bazılarının ise tamamen yasadışı ilan etmeye kadar veren muhafazakâr politikaları benimsediği görülmektedir. Örneğin Çin kripto para ihracını ve özel borsalarda alım satımını yasakladıktan sonra bunlarla ilgili her türlü web sitesine de erişim engeli getirmiştir (Elliot vd. 2018, s. 41). Diğer yandan Japonya ve Avustralya kripto paraları resmi ödeme aracı ve finansal varlık olarak kabul etmektedirler. Merkez Bankası'nın kendi dijital parasını çıkarmasını savunan Bordo ve Levin'in (2017) çalışmasına göre bu avantajlı bir kamu politikasını tercih eden Ekvator ve Kenya gibi bazı üçüncü dünya ülkelerinde merkez bankası gözetimi altında aracı platformlarla anlaşılarak dijital para uygulamalarına başlanılmıştır. Bazı ülkeler ise doğrudan kendi kripto paralarını üretme yolunu seçmiştir. En büyüğü Çin olan bu ülkeler arasında Litvanya İrlanda Venezüella ve bazı ada ülkeleri yer almaktadır. Tablo 3'de Türkiye'nin de aralarında bulunduğu bazı ülkelerin kripto paraların beraberinde getirdiği politika sorunlarına karşı yaptıkları politika tercihleri, bu çalışmada yapılan analizlerden de yararlanılarak 10 ayrı grupta derlenmiştir.

\begin{tabular}{|c|c|c|}
\hline \begin{tabular}{|l|l|} 
Eylem \\
No
\end{tabular} & Politika Tercihi & Ülkeler \\
\hline 1 & Kamu otoritelerince kamuoyunun yazilı olarak uyarilması & İngiltere,Türkiye(*), Belçika, Danimarka, Finlandiya \\
\hline 2 & $\begin{array}{l}\text { Para aklama ve Antiterörizmle ilgili yasaların kripto paraları kapsayacak } \\
\text { șekilde yenilenmesi }\end{array}$ & Avustralya, Kanada, Man Adası \\
\hline 3 & Tam yasaklama & Cezayir, Bolivya, Misır Fas, Irak, Pakistan \\
\hline 4 & $\begin{array}{l}\text { Vatandaşların değil, finansal kurumların faaliyetlerinin yasaklanarak } \\
\text { işlemlerin dolaylı olarak kısıtlanması }\end{array}$ & İran, Banglades, Tayland, Cin, Kolombiya \\
\hline 5 & $\begin{array}{l}\text { Kurum/kişilere piyasaya yeni kripto para arzı (ICO)yoluyla fon tedarikine } \\
\text { izin verme (yasaklama) }\end{array}$ & Çin, Pakistan \\
\hline 6 & $\begin{array}{l}\text { Kurum/kişilere piyasaya yeni kripto para arzı yoluyla fon tedarikine izin } \\
\text { verme (koşullu izin) }\end{array}$ & Yeni Zellanda, Hollanda \\
\hline 7 & $\begin{array}{l}\text { Yasal para birimi olarak tanımadan, yatırım çekme amaçlı kripto para- } \\
\text { dostu düzenlemeler yapma }\end{array}$ & İspanya, Belarus, Kayman Adaları,Lüksemburg \\
\hline 8 & Kendi kripto parasını çıkarma & Venezüella, Litvanya (Çin ve İrlanda proje așamasında) \\
\hline 9 & Kripto para gelirlerini vergilendirme & İsrail, Bulgaristan, İsviçre, Arjantin, Danimarka, İngiltere \\
\hline 10 & Ülke parası ile aynı düzeyde ödeme aracı olarak kabul etme & Man Adası, Meksika \\
\hline
\end{tabular}


Tabloda sunulan politika eylemleri göz önüne alınarak, dünya genelindeki kripto para politikalarında liberal ve muhafazakâr olarak iki temel yaklaşım olduğu söylenebilir

Kripto paralarla ilgili özellikle gelişmiş ülkelerde daha liberal politikalar izlenmektedir. Danimarka, İngiltere, İsveç, Güney Kore, Hollanda, Birleşik Krallık, Güney Kore ve Avustralya'yı sanal para dostu ülkeler arasında sayılmaktadır (Çarkacıoğlu, 2016, s. 57). Kripto parayı mal değil hizmet olarak gören Finlandiya ve kara para aklama düzenlemeleri yapmakla beraber kullanımına izin veren Kanada da bu gruba dahil edilebilir. En liberal kripto para rejimleri ise kripto parayı ülke parasıyla eş değer tutan Meksika ve Man Adası'nda benimsenmiştir. Danimarka, kendi merkez bankasından da tamamen vazgeçmeden, kripto paraları ve itibari dijital parasını beraberce günlük yaşamda kullanmayı planlamaktadır. Danimarka Merkez Bankası, kripto paranın bir para olmadığını, bu sebeple regüle etmeyeceklerini açıklamıştır. Ülke aynı zamanda kamuoyunu kripto paraların mevduat gibi güvence altında olmadığı ve olası riskler karşısında uyarmaktadır. Ülkenin vergi konseyi ise kripto para kazançlarını gelir vergisine tabi tutarken, değer kayıplarının vergiden tenzil edilebileceğine karar vermiştir. İngiltere'de yaygın olarak kullanılan kripto paralar yaygın bir mübadele aracıdır ve yapılan alışverişlere katma değer vergisi uygulanmaktadır. İngiltere Merkez Bankası kamuoyunu dönemsel olarak uyarsa da kripto para kullanımını ülkenin finansal istikrarına zarar vermeyeceğini bildirmiştir. Diğer yandan kripto para alım satımından elde edilen kazançları sermaye kazancı olarak vergilendirmektedir (The Law Library of Congress, 2018; Çarkacioğlu, 2016, s. 57).

İsveç Merkez Bankası'nın negatif faiz uygulamasından etkilenmemek için, İsveç vatandaşları kripto paraları kullanabilmektedirler. İsveç Finansal Denetleyici Otoritesi de, kripto paraları ödeme metodu olarak yasallaştırmıştır. Güney Kore'de, kripto paraları düzenleyen bir yasa olmamasına rağmen, bunlar fiilen ödeme yöntemi olarak kabul görmüş̧ür ve her geçen gün yaygınlığı artmaktadır. Hollanda da kripto paralar herhangi bir sınırlama olmaksızın yaygın olarak kullanılmaktadır. Avustralya kripto paralarda çifte vergilendirmeyi kaldırmış ve bunları hukuk sistemine emtia olarak dahil etmiştir (The Law Library of Congress, 2018). Finlandiya Merkezi Vergi Kurulu, kripto paraları bir finansal hizmet olarak tanımlamış ve katma değer vergisinden muaf tutmuştur. Kanada da kripto paralarla ilgili kara para aklama gibi konularda önemli düzenlemeler eşliğinde kullanımı açısından yenilikçi ve liberal politikalar izlemektedir. Ülkede bu paralar kara para aklama ve terörün finansmanı mücadelesi yasası kapsamında düzenlenmiştir. Bu arada aralarında İspanya, Belarus, Kayman Adaları ve Lüksemburg gibi ülkelerin bulunduğu bir grup 
devlet kripto paraları yasal para birimi olarak benimsememiş olmakla beraber yatırım çekme amacıyla dolaşımı ve işlem görmesi konularında liberal bir tutum izlemektedir.

Liberal politikaların izlendiği Avrupa ülkeleri ile Kanada ve Avustralya gibi finansal ve ekonomik gücü yerinde olan ülkelerin aksine az gelişmiş ülkelerde kripto paralarla ilgili daha muhafazakâr ya da büsbütün yasakçı politikalar izlendiği görülmektedir. Ancak Belçika ve İzlanda gibi kripto paralara karşı temkinli yaklaşan ülkeler bu durum için bir genelleme yapılmasını zorlaştırmaktadır. Çarkacıoğlu (2016) kripto para satın alınmasını yasa dışı ilan eden İzlanda ile birlikte Bangladeş, Bolivya, Ekvator ve Tayland'1 "Bitcoin düşmanı" ülkeler olarak sınıflandırmaktadır.

Bangladeş, kripto paraları yasal bir para olmadığı ve kullanıcılarını finansal tehlikelere atabileceği için yasaklamıştır. Bolivya Merkez Bankası, "bir hükümet veya yetkili birimler tarafından çıkartılmayan ve kontrol edilmeyen paraları kullanmak yasal değildir" gerekçesiyle, Ekvator ise kendi elektronik parasını ile rekabeti önlemek için kripto paraları yasaklamıştır. Tayland Merkez Bankası, 2013 yılında kripto para kullanımının yasal olmadığını duyurmuştur (Çarkacıoğlu, 2016:58). Çarkacıoğlu'nun (2016) sınıflandırmasına uygun olarak Belçika da kripto paraların para sayılamayacağını açıklamış olup, kullanıcıları risklere karşı uyarmaktadır. Sınıflandırmada yer almayan üçüncü dünya ülkelerinden Cezayir 2018 yılında özel bir yasa çıkararak kripto paralar1 yasaklarken, Mısır'da 2017 yılında kripto paranın haram olduğuna dair bir de fetva yayınlanmıştır. Bolivya ve Fas'ta da kripto para kullanımı yasaktır. Irak ise kesinlikle yasakladığı kripto para kullanıcılarını doğrudan kara para aklama suçundan yargılamakta, Pakistan'da ise 2017'den bu yana kullanıcılar hakkında federal takibat yapılmaktadır (Elliott vd., 2018; CRS, 2020).

\section{Sonuçlar}

Başlangıçta dijital, anonim, hızlı ve güvenli bir ödeme enstrümanı olarak tasarlanan kripto paralar kısa sürede dünyanın bütün ülkelerinde yaygınlaşmış, ödemelerde kullanıldığı kadar, dönemsel değer artışları nedeniyle popüler bir yatırım aracına da dönüşmüştür. Tipik olmayan işleyiş biçimi kripto paraların bir mübadele aracı olarak kara para aklama ve terörün finansmanı gibi yasa dışı aktivitelerde kullanımını kolaylaştırmaktadır. Her gün çeşitlenen ve yenileri ihraç edilen kripto paralar merkez bankalarının para üzerindeki egemenliğine de zarar verme potansiyeli taşımaktadır. Anonim ve kriptolu yapısı nedeni ile hukuk sistemindeki karşılığının tanımlanması zor, ancak itibari paraya dönüşebilmesi ve mülkiyet konusu olması nedeniyle elzem olan kripto paralar hukukun birçok alanında boşluk yaratmaktadır. Bu durum kamu 
maliyesi için de kripto para harcamalarından alınan dolaylı vergiler ve değer artışlarından kaynaklanan sermaye kazançları konularında bir belirsizlik yaratmaktadır.

Kripto paraların bireyler için yarattığı en önemli sorunlar ise siber hırsızlıklar ve değiş tokuş borsalarındaki dolandırıcılıklardır. Yasal düzenleme eksikliklerinden kaynaklanan bu suç riskleri yanında kullanıcılar aşırı değer kayıpları durumunda spekülatif risklere de maruz kalmaktadır. Kısaca kripto paraların hem kamu otoriteleri hem de kullanıcısı olan bireyler için beraberinde getirdiği birçok politika sorunu bulunmakta, ancak bu sorunlar teknolojik ve finansal avantajları nedeni ile kullanımının ve bilinirliğinin artmasına engel olamamaktadır. Bu durumda kripto para sorunlarının politika gündemine alınması ve uygun kamu politikaları geliştirilerek kripto paralarla ilgili uygun düzenlemelerin yapılması gerektiği tabiidir. Karşılaştırmalı olarak incelendiğinde kripto paraların doğurduğu politika sorunlarının ortak olduğu, bu sorunlarla ilgili her ülkenin kendisine özgü kripto para politikaları geliştirdiği ve geniş bir yelpazedeki politika araçlarından yararlandığı görülmüştür.

Türkiye'de ise kamu otoriteleri 2021 yılına kadar kripto paraların regülasyonu için belirgin ve etkin bir kamu politikası geliştirmemiştir. Bunun basit bir tahlille anlaşılabilir iki görünür nedeni vardır. Birincisi özellikle TCMB ve BDDK gibi yetkili otoritelerin kripto paraları alelade bir mübadele aracı olarak ele alınmasıdır. Kripto paralar dijital ödeme sistemlerindeki diğer enstrümanlar ve gelişmeler evreninde değerlendirilmiş, kripto paraların aslında bir yatırım aracı olarak Türkiye'yi istatistiklerde ön sıralara taşıyan popülerliği ve yüksek kullanıcı sayısı dikkate alınmamıştır. Bir yatırım aracı olarak Borsa İstanbul'un 4te1'i tutarında işlem görmeye başladığı 2021 yılına kadar, kripto para işlemlerinin kontrol dışında bırakıldığ 1 ve ihmale yakın tutum benimsendiği görülmektedir. Sonuçta aracı platformlarının düzenleme ve kontrol dış1 kalmasının yol açtığı dolandırıcılıklar karşısında tüketici kayıpları yaşanmıştır. İkincisi ise TCMB, BDDK, SPK, Hazine ve Maliye Bakanlığı gibi önemli aktörlerin bir arada ve eşgüdümlü bir kamu politikası ve buna yönelik düzenlemeler geliştirmekte zorlanmış olmasıdır. Karar verme süreçleri şeffaf olmadığ için bu kurumlarda kripto paralarla ilgili olarak görevlendirilen çalışma gruplarının raporları veya önerilen ama gündeme alınmayan formülasyonlar üretilip üretilmediği konuları bilinememektedir. Politika sorunlarına her biri kendi çözüm arayan ama ortak çözüm üretememiş olan bu aktörlerin karşılaştığı en büyük güçlük, kripto paralarla ilgili hukuki boşluktur. Bunun için söz konusu aktörlerin yasama yetkisini haiz TBMM'ni veya Cumhurbaşkanlı̆̆ı'nı bu konuda ikna etmesi, yönlendirmesi ve mobilize etmesi beklenirdi. TCMB tarafından yasaklama olarak yorumlanabilecek 2021 y1lı regülasyonu yasal 
hiyerarşi içerisinde güçlü değildir ve hukuki boşluğa yanıt vermekten çok palyatif bir çözüm olmuştur. Kanımızca tutarlı ve kapsamlı bir kripto para politikası geliştirilebilmesi için dünyadaki örneklerin değerlendirildiği karş1laştırmalı bir bakış açısı yararlı olabilir.

Dünyada küreselleşme ile birlikte ülkelerin finansal sistemleri birbiriyle uyumlu çalışacak şekilde evrilmişler, merkez bankaları ve düzenleyici ve denetleyici kurullar neredeyse standartlaşacak şekilde benzer bir şekilde örgütlenmişlerdir. Bir başka deyişle finansal sistemdeki aktörler 1980^li yıllardan bu yana yoğun bir politika transferi ile gelişmekte olan ülkelerde de ihdas edilmişler ya da mevcut aktörler yeni gelişme ve örgüt modellerine uyarlanmıştır. Türkiye'de de Merkez Bankası benzer bir dönüşüm geçirmiş bu çalışmada tutumları incelenen BDDK, SPK, Borsa İstanbul ve MASAK gibi düzenleyici veya denetleyici kurum ve yapıların tamamı 1980 sonrası gelişmelerle birlikte özellikle batıdaki modellerden ilham alınarak veya düpedüz kopyalanarak kurulmuşlardır. Bu nedenle kripto paralar gibi belirli bir merkezi olmayan finansal araç ve yarattığı özgün işleyişin denetlenmesi ve/ veya uyarlanması için diğer ülkelerde izlenen politikaların uyarlaması, sistem benzerlikleri göz önüne alındığında daha kolay olabilecektir. Ülkeler kendi koşullarına göre kripto paralarla ilgili muhafazakâr ve yasaklayıcı modeller geliştirebildikleri gibi, bunlara tamamen cevaz veren ve kendi finansal sistemlerine entegre eden çok liberal modeller de uygulayabilmektedir. Türkiye'de kendi kripto para politikalarını geliştirirken bu modellerden birini benimseyebilir veya her iki politika tutumunun belirli tutumlarını melezleyerek kendi mali ve ekonomik koşullarına uygun politikaları kolaylıkla geliştirebilir. $\mathrm{Bu}$ kolaylığın nedeni bütün dünyada aynı şekilde işleyen kripto paraların benzer sistemler için aynı sorunları üretmesidir. Türkiye'nin kripto paraların yarattığı politika sorunlarını çözebilmesi için yeni baştan bir politika tasarlaması gerekmiyor olması avantajlı bir durumdur. Şimdiye kadar politika üretmekte isteksiz ve geç kalmış görünen ülkenin bahsedilen avantajını kullanarak, uygun politikaları transfer etmesi ve uyarlaması, karar verici aktörlerini eş güdüm içerisinde harekete geçirmesiyle mümkün olabilecektir. 


\section{Kaynakça}

Ak, R. (2017). Adına 'Emtia' Dersek Bitcoin'e Vergi Gelir. https://www.haberturk.com/tv/ ekonomi/haber/1752729-Bitcoin-e-vergi-mi-geliyor

Aky1l, Z. (2018). Finansal İstikrar Komitesinden Bitcoin Uyarısı. https://www.aa.com.tr/tr/ekonomi/finansal-istikrar-komitesinden-Bitcoin-uyarisi/1028439

Aydoğan, Y. (2019). Masak’tan Sevindiren Bircoin Düzenlemesi. https://www.coinmoz.com/ masaktan-sevindiren-Bitcoin-duzenlemesi/

Bardach E. \& Patashnik E. M. (2016). A Practıcal Guide For Policy Analysis. London: Sage Publications.

Bayar, K. (2019). Sermaye Piyasası Kurulu'nun (SPK) Yayınladığı Tebliğ Kripto Parayı İ1gilendiriyor. Erişim Adresi https://beincrypto.com.tr/sermaye-piyasasi-kurulunun-spkyayinladigi-teblig-kripto-parayi-ilgilendiriyor/

Buchholz, K. (10.08.2020). How Common Is Crypto?. https://www.statista.com/chart/18345/ crypto-currency-adoption/

BDDK (2013). Basın Açılaması 25.11.2013/32. https://www.bddk.org.tr/ContentBddk/dokuman/duyuru_0512_01.pdf

BDDK (2014a). Ödeme Hizmetleri Ve Elektronik Para İhracı İle Ödeme Kuruluşları Ve Elektronik Para Kuruluşları Hakkında Yönetmelik. RG:27.06.2014/29043.

BDDK (2014b). Ödeme Kuruluşları Ve Elektronik Para Kuruluşlarının Bilgi Sistemlerinin Yönetimine Ve Denetimine İlişkin Tebliğ. RG:27.06.2014/29043.

BDDK (2019a). Sıkça Sorulan Sorular/Ödeme Sistemleri ve Elektronik Para Kuruluşları. https:// www.bddk.org.tr/Sss-Kategori/Odeme-Sistemleri-ve-Elektronik-Para-Kuruluslari/3

BDDK (2019b). Ödeme Hizmetleri ve Elektronik Para İhracı İle Ödeme Kuruluşları ve Elektronik Para Kuruluşları Hakkında Yönetmelik. RG:27.06.2014/29043.

BIS (2011). Committee on Payment and Settlement Systems; 2011Survey Of Electronic Money Developments. Basel: Bank for International Settlements Pub.).

Bordo, M. \& Levin, A. (2017). Central Bank Digital Currency And The Future Of Monetary Policy. Cambridge, MA: National Bureau Of Economic Research.

Ciphertrace (2020). Cryptocurrency Anti-Money Laundering (AML) Report. https://ciphertrace.com/q2-2019-cryptocurrency-anti-money-laundering-report/

Ciphertrace (2021). Cryptocurrency Anti-Money Laundering (AML) Report. https://ciphertrace.com/2020-year-end-cryptocurrency-crime-and-anti-money-laundering-report/

CRS (2020). Cryptocurrency: The Economics of Money Selected Policy Issues. https://fas.org/ sgp/crs/misc/R45427.pdf

Cumhurbaşkanlığı (2019a). 11. Kalkınma Planı (2019-2023). http://www.sbb.gov.tr/wpcontent/uploads/2019/07/OnbirinciKalkinmaPlani.pdf

Cumhurbaşkanlığı(2019b). Cumhurbaşkanlığı2020yılı Yıllık Programı. RG: 04.11.2019:30938.

Cumhurbaşkanlığı (2020). Karar No:3030. RG: 29.09.2020, 31259 Mük.

Çarkacıoğlu, A. (2016). Kripto Para-Bitcoin. SPK Araştırma Raporu. https://www.spk.gov.tr/ SiteApps/Yayin/YayinGoster/1130 
Donanım Haber (2019). MASAK'tan Kripto Para Yatırımcılarına İyi Haber. https://www.donanimhaber.com/MASAK-tan-kripto-para-yatirimcilarina-iyi-haber--114467

Elliott, D. J., De Lima, L. \& Singel, R. (2018). Cryptocurrencies And Public Policy Key Questions And Answers. New York: Oliver Wyman Press.

Eser, S. (2019a). Sıcak Gelişme: Türk Bitcoin Borsası Hacklendi ve Kapanıyor!. https://kriptokoin.com/sicak-gelisme-populer-turk-Bitcoin-borsasi-hacklendi-ve-kapaniyor/

Eser, S. (2019b). Son Dakika: Popüler Türk Bitcoin Borsas1 Hackendi! Binlerce Ripple, Ethereum ve Altcoin Çalındı!. https://kriptokoin.com/son-dakika-populer-turk-Bitcoin-borsasihackendi-binlerce-ripple-ethereum-ve-altcoin-calindi/

Finansal İstikrar Komitesi (2018). Basın Açıklaması Sayı: 2018/3. https://115101-327832rai kfcquaxncofqfmstackpathdns.com/wpcontent/uploads/2018/03/Kripto_Paralara_Iliskin_ Hazine_Mustesarligi_Aciklamasi_11012018.doc?x92415

Görmez B. (2017). Finansal Sektörde Yıkıcı Yenilik: Dağıtılmış Defter Teknolojisi ve Türkiye Sermaye Piyasalarının Durumu. https://www.spk.gov.tr/SiteApps/Yayin/YayinGoster/1136

Hayes, M. T. (1992). Incrementalism and Public Policy. New York:Longman.

Hazine ve Maliye Bakanlığı (2020) 2019 Yılı Faaliyet Raporu. https://ms.hmb.gov.tr/ uploads/2020/07/Hazine-ve-Maliye-Bakan1\%C4\%B1\%C4\%9F\%C4\%B1-2019Y\%C4\%B11\%C4\%B1-\%C4\%B0dare-Faaliyet-Raporu-1.pdf

Hazine ve Maliye Bakanlığ1 (2021). Ekonomi Reformu Takvimi. https://ms.hmb.gov.tr/uploads/2021/03/Ekonomi-Reform-Takvimi.pdf

İndigo Dergisi (2017) Diyanet’ten Bitcoin ve Ethereum Kripto Para Birimleri Açıklaması. https://indigodergisi.com/2017/11/diyanet-Bitcoin-ethereum-kripto-para/

Jahn, W. \& Wegrich, K. (2007). Theories of the Policy Cycles. In Fischer, F., Miller G. J. \& Sydney, M.S. (Eds.), Handbook of Public Policy Analysis (pp. 43-63). Boca Raton: CRC Press.

Kanun No:1211, RG:26.01.1970/13409.

Kanun No:4059, RG:09.12.1994/22147.

Kanun No:6493, RG:27.06.2013/28690.

Kanun No:7161, RG:18.01.2019:30659.

Kaplanhan, F. (2018). Kripto Paranın Türk Mevzuatı Açısından Değerlendirilmesi: Bitcoin Örneği. Vergi Sorunları Dergisi, S.353, 105-123.

Kartal, B. (2019). Türkiye'de 13 Milyon TL Değerinde Kripto Para Vurgunu İddiasıyla 23 Kişi Gözaltına Alınd1, https://www.webtekno.com/turkiye-de-13-milyon-tl-degerinde-kriptopara-vurgunu-iddiasiyla-23-kisi-gozaltina-alindi-h62545.html

Koçoğlu, Ş, Çevik, Y.E. \& Tanrı̈ven, C. (2016). Bitcoin Piyasalarının Etkinliği, Likiditesi ve Oynaklığı. İşletme Araştırmaları Dergisi, S. 8/2, 77- 97.

Kripto Para Türkiye (2019). Masak’tan Kripto Paralar ile İlgili Yeni Tanım. https://www.kriptoparaturkiye.com/masak-kripto-para/.html

Martucci, B. (2019). What Is Cryptocurrency - How It Works, History \& Bitcoin Alternatives, https://www.moneycrashers.com/cryptocurrency-history-Bitcoin-alternatives/, 
MASAK (2014). Şüpheli İşlem Bildirim Rehberi- Bankalar. https://docplayer.biz.tr/582536Supheli-islem-bildirim-rehberi-bankalar.html

MASAK (2015). 2014 Y1l Faaliyet Raporu. https://ms.hmb.gov.tr/uploads/2019/01/MASAK2014-FAAL\%C4\%B0YET-RAPORU.pdf

MASAK (2019). Şüpheli İşlem Bildirim Rehberi- Bankalar. https://ms.hmb.gov.tr/uploads/2019/09/MSK-RHB-\%C5\%9E\%C4\%B0B-001-1.4.pdf

Milijic, M. (2019). 37+ Cryptocurrency Stats Every Investor Must Know in 2019. Leftronic. https://leftronic.com/cryptocurrency

Milliyet (2021). Son dakika: Bir skandal daha! ve Bitcoin de kapandı MASAK harekete geçti. https://www.milliyet.com.tr/ekonomi/son-dakika-bir-skandal-daha-veBitcoin-dekapandi-masak-harekete-gecti-6489202

Parsons, W. (1995). Public Policy: An Introduction To The Theory And Practice Of Policy Analysis. Aldershot: Edwar Algar Publications.

SPK (2017). Sanal Paralara Dayalı İşlemler Hk. TSPB'ne Bildirim: 01.2.2017 Tarih ve E.13447. https://www.tspb.org.tr/wp-content/uploads/2017/12/Genel-Mektup-785-SanalParalara-Dayal\%C4\%B1-\%C4\%B0\%C5\%9Flemler-hk..pdf

SPK (2018). Sermaye Piyasası Kurulu Bülteni 2018/42 Dijital Varlık (Token) Satışlar1 (ICO) Hakkında Duyuru 2018/42 27/09/2018. https://www.spk.gov.tr/Bulten/ Goster?year $=2018 \&$ no $=42$

SPK (2019). Paya Dayalı Kitle Fonlaması Tebliği. RG:03.10.2019/30907.

Statista (2021). Average Number of Daily Active Users (DAU) of Selected Apps That Allow For Cryptocurrency Storage İn Turkey From January 2017 To February 2021. https:// www.statista.com/statistics/1222485/most-popular-cryptocurrency-wallets-turkey/

Taşç1, B. (2021). Son Dakika Haberi: Türkiye'nin Konuştuğu Thodex Vurgunu! Kripto Para Dünyas1 Şokta. https://www.hurriyet.com.tr/ekonomi/son-dakika-haber-turkiyeninkonustugu-thodex-vurgunu-kripto-para-dunyasi-sokta-41794316

TCMB (2017). Soru Önergesi Yazılı Cevabı: 13 Kasım 2017/S:30030. https://www2.tbmm. gov.tr/d26/7/7-17304c.pdf

TCMB (2019). Ödeme Sistemlerinin Finansal Piyasa Altyapılarına İlişkin Prensiplere Uygunluk Beyanı. https://www.tcmb.gov.tr/wps/wcm/connect/c34c2e8a803a-4713-9c60-842232677d67/FPAiP_KamuyaBeyan_Yay\%C4\%B1m3_2019. pdf?MOD=AJPERES\&CVID

TCMB (2021). Ödemelerde Kripto Varlıkların Kullanılmamasına Dair Yönetmelik. RG:16.04.2021/31456.

The Law Library of Congress (2018) Research Report: Regulation of Cryptocurrency Around the World. https://www.loc.gov/law/help/cryptocurrency/cryptocurrency-world-survey. pdf

TRT Haber (2018a). Diyanet’ten Bitcoin Açıklaması: Dijital Kripto Paraların Kullanımı Caiz Değil. https://www.trthaber.com/haber/ekonomi/diyanetten-Bitcoin-aciklamasi-dijitalkripto-paralarin-kullanimi-caiz-degil-345100.html

Turhan, M. (2018). Bitcoin'in Türkiye'de Yasal Statüsü. https:/turhanturhan.com/2018/05/03/ Bitcoinin-turkiyede-yasal-statusu/ 
Uyar, E. (2018). Kripto Paralarda (Bitcoin) Hırsızlık ve Yağma Suçu. https://www.hukukihaber.net/kripto-paralarda-Bitcoin-hirsizlik-ve-yagma-sucu-makale,6293.html

Vatan (2021). Goldexco.in'de İşlemler Durduruldu! Kripto Para Piyasasında Üçüncü Şok!. http://www.gazetevatan.com/goldexco-in-de-islemler-durduruldu-kripto-parapiyasasinda-ucunc-1386976-ekonomi/

Yardımcı, N. (2021). Merkez Bankası Kendi Dijital Parasını Üretiyor. Trthaber. https://www. trthaber.com/haber/ekonomi/merkez-bankasi-kendi-dijital-parasini-uretiyor-555201.html

Yüksel, S. (2021). Türkiye'de Kripto Para Günlük İşlem Hacmi 1 Milyar Doları Aştı. Bloomberght. https://www.bloomberght.com/turkiye-de-kripto-para-gunluk-islem-hacmi-1milyar-dolari-asti-2271922 
